\title{
Lithostratigraphy and Sedimentological Characteristics of the Calciturbidites of the Babadağ Formation-Tavas Nappe (SW Turkey)
}

\author{
Basiru Mohammed Kore ${ }^{1}$, Murat Gül1, ${ }^{1}$, Ceren Küçükuysal ${ }^{1}$ and Bilal Sarı² \\ ${ }^{1}$ Muğla Sıtkı Koçman University, Faculty of Engineering, Department of Geological Engineering, 48000, Muğla, Turkey; \\ (princebmKORE,@yahoo.com; cerenkucukuysal@mu.edu.tr; "corresponding author: muratgul@mu.edu.tr; muratgul.geol@gmail.com) \\ 2 Tınaztepe Campus, Dokuz Eylül University, Faculty of Engineering, Department of Geological Engineering, 35160, Buca-Izmir, Turkey; (bilal.sari@deu.edu.tr)
}

doi: $10.4154 / g c .2021 .01$

Article history:

Manuscript received December 19, 2019 Revised manuscript accepted October 14, 2020 Available online February 28, 2021

Keywords: Facies Zone - Standard Microfacies (FZ - SMF, FLÜGEL, 2004), Deep-Sea, Lycian Nappes, Muğla-SW Turkey.

\begin{abstract}
The Lycian Nappes contain slices of ophiolites and sedimentary rocks of various ages that crop out in SW Turkey. They evolved and were emplaced under the effect of the Late CretaceousMiocene compressional regime. The Tavas Nappe is part of the Lycian Nappes and contains Jurassic-Eocene sediments. The Babadağ Formation, forming the middle part of the Tavas Nappe, is composed of limestone at the base and various sized calciturbidites with chert intercalations in the upper part. The Standard Microfacies Classification (SMF of FLÜGEL, 2004) indicates that the entire unit was deposited mainly in a deep-shelf environment (Facies Zone FZ-2), deep-sea (FZ-1), toe of slope (FZ-3) and on the continental slope (FZ-4). Calcite and quartz dominate the bulk mineralogy of the calciturbidites with higher $\mathrm{SiO}_{2}$ and $\mathrm{CaO}$ weight percentages than other major oxides. Additionally, the presence of $\mathrm{Na}_{2} \mathrm{O}, \mathrm{K}_{2} \mathrm{O}, \mathrm{Al}_{2} \mathrm{O}_{3}, \mathrm{MgO}, \mathrm{TiO}_{2}$ and $\mathrm{Fe}_{2} \mathrm{O}_{3}$ is associated with the local sediment input. Tectonism and sea level fluctuations were the main triggering factors of the changes in the original depositional environment of the Babadağ Formation. Additionally, grain size and the amount of sediment input control the calciturbidite type and extension. Si enriched water circulation and Si and Ca substitution were responsible for the abundant chert formation during diagenesis of the units. Post depositional tectonic activities during transportation and emplacement of the nappes resulted in calcite filled cracks that cut both the calciturbidites and cherts. Study of the different nappe slices provides valuable information about syn- and post- depositional changes of the lithostratigraphic units.
\end{abstract}

\section{INTRODUCTION}

Calciturbidites occur in various sedimentary environments such as continental slopes, toe of slope and single or multiple feeding submarine fans (WATTS, 1987; RUBERT et al., 2012; HAIRABIAN et al., 2015). They can also be associated with different parts of carbonate platforms and platform margins (REIJMER et al., 2015a, 2015b). The most important characteristic that distinguishes calciturbidites from siliciclastic deposits of the deep sea are the unique diagenetic process of dolomitization, silicification (chert layers or lenses) and micritization (EBERLI, 1991; RUBERT et al., 2012; GÜL, 2015). Calciturbidites are generally characterized by poor sorting, local inverse grading, diagenetic micritic layers embedded in the base and nodular silica layering (EBERLI, 1991). Chertification due to diagenesis affects the porosity and permeability of the host rocks (McBRIDE et al., 1999; SALLER et al., 2001; BEHL, 2011). The sedimentation in carbonate gravity systems is controlled by sea level fluctuations, source region, regional basin tectonics and slope characteristics (e.g., EBERLI, 1991; PAYROS \& PUJALTE, 2008). REIJMER et al. (2015a) emphasized that calciturbidites are of interest to the oil and gas industry because of their porous and permeable granular structure.

Although studies have shown calciturbidites to crop out in various regions with different ages, fewer studies have been carried out on the calciturbidites in comparison to siliciclastic turbidites. The calciturbidites of the Babadağ Formation (in this manuscript), are similar to the calciturbidites from the Southern
Provence Basin, Turonian-Cenomanian, France (REIJMER et al., 2008, 2012; REIJMER et al., 2015a, 2015b); the Late TriassicEarly Jurassic of Northern Hungary (HAAS et al., 2010); Jurassic Tethys Oceanic Carbonate deposits of Eastern Alps-Switzerland (EBERLI, 1987); the Early Cretaceous of the Manim unit, Western Carpathians Slovakia (MICHALIK et al., 2012); the Late Cretaceous of the Ionian Basin-Central Albania (DEWEVER et al., 2007) and the Cretaceous of the Othris Mountain-Hellenide zone and Eastern Greece (PRICE, 1977). Some older calciturbidites were reported in different countries; the Silurian-Devonian calciturbidites of the Barrandian Region-Czech Republic, (VACEK, 2007); the Early-Middle Triassic Sumeini Group, Maqam Formation, northernmost Arabian Carbonate Platform (WATTS, 1987); and the Triassic Pedata / Potschen Formation calciturbidites-Austria (REIJMER et al., 1991).

In Turkey, ROBERTSON \& WOODCOCK (1981) documented the Upper Triassic calcareous clastics and the JurassicLower Cretaceous siltstone-radiosphere-chert-mudstone-limestones and black shales in Antalya-SW Turkey. SOFRACIOĞLU \& KANDEMIR (2013) and SARI et al. (2014) reported the Upper Mesozoic calciturbidites in the Eastern Pontides-NE Turkey. ÖZCAN et al. (2012) mentioned the Upper Cretaceous-Eocene pelagic micrites and calciturbidites of the Black Sea shoreline and the Western Pontides-N Turkey. SOLAK et al. (2015) documented some Upper Cretaceous calciturbidites in the Bornova Flysch Zone in the Manisa-Spil Mountain-W Turkey (Fig. 1). 
The Lycian Nappes are sandwiched between the Beydağları Autochthone to the south and the Menderes Massif to the north in the Tauride-Anatolide Platform of Turkey (Fig. 1). They are mainly composed of allochthons with remnants of oceanic crust that encompass diverse deep-water and platform type deposits (DANELIAN et al., 2006; GÖNCÜOĞLU, 2011; MOIX et al., 2013; SARI, 2017). The Lycian Nappes (including deep-water sediments of the Tavas Nappe), have since become a subject of widespread interest for numerous researchers over the last four decades, focusing on the fossil content and local lithological characteristic of the units (YILMAZ, 1981; ERAKMAN et al., 1982; ŞENGÖR et al., 1984; OKAY, 1989; ŞENEL et al., 1994; KOZUR, 1998; COLLINS \& ROBERTSON, 1998, 1999; ÖZCAN et al., 2012; GÜL et al., 2013; GÜL, 2015; SOYCAN et al., 2015; SARI, 2017). However, determination of the differences of nappe slices, which are thought to be the product of the same environment and when separated are mapped under the same nappe name, can provide valuable information about the primary-original depositional environment. This depositional environment can be quite large. As a result, the lithological-compositionaltextural-structural differences detected in each nappe slice can help identify the characteristics of the depositional environment both syn- and post- sedimentation. Thus, calciturbidites in the upper part of the Babadağ Formation require additional studies for a complete understanding of the carbonate gravity-flow deposits.

Therefore, this study aims (1) to determine the detailed sedimentological characteristics of the calciturbidites of the Babadağ Formation mapped as separated slices which together comprise the Tavas Nappe (Fig. 2), and (2) to unravel the depositional environment and controlling factors on the calciturbidite sediments.

\section{GEOLOGICAL SETTING}

SW Turkey contains three major geological units; the Beydağları Autochthone, the southern Menderes Massif and the Lycian Nappes allochthones which crop out between these two autochthones (Fig. 1).

The Beydağları Autochthone includes Late Triassic-Cretaceous platform carbonates and the Lutetian-Miocene sediments (Fig. 3; ERSOY, 1990; ŞENEL et al., 1989, 1994, 1998; SARI \& ÖZER, 2001; 2002; SARI et al., 2004; SARI, 2006; 2017; ŞENEL, 2004, 2007; SOYCAN et al., 2015). The core of the southern part of the Menderes Massif contains gneiss and meta-gabbro at the core; the cover part includes Upper Devonian-Early Eocene am-

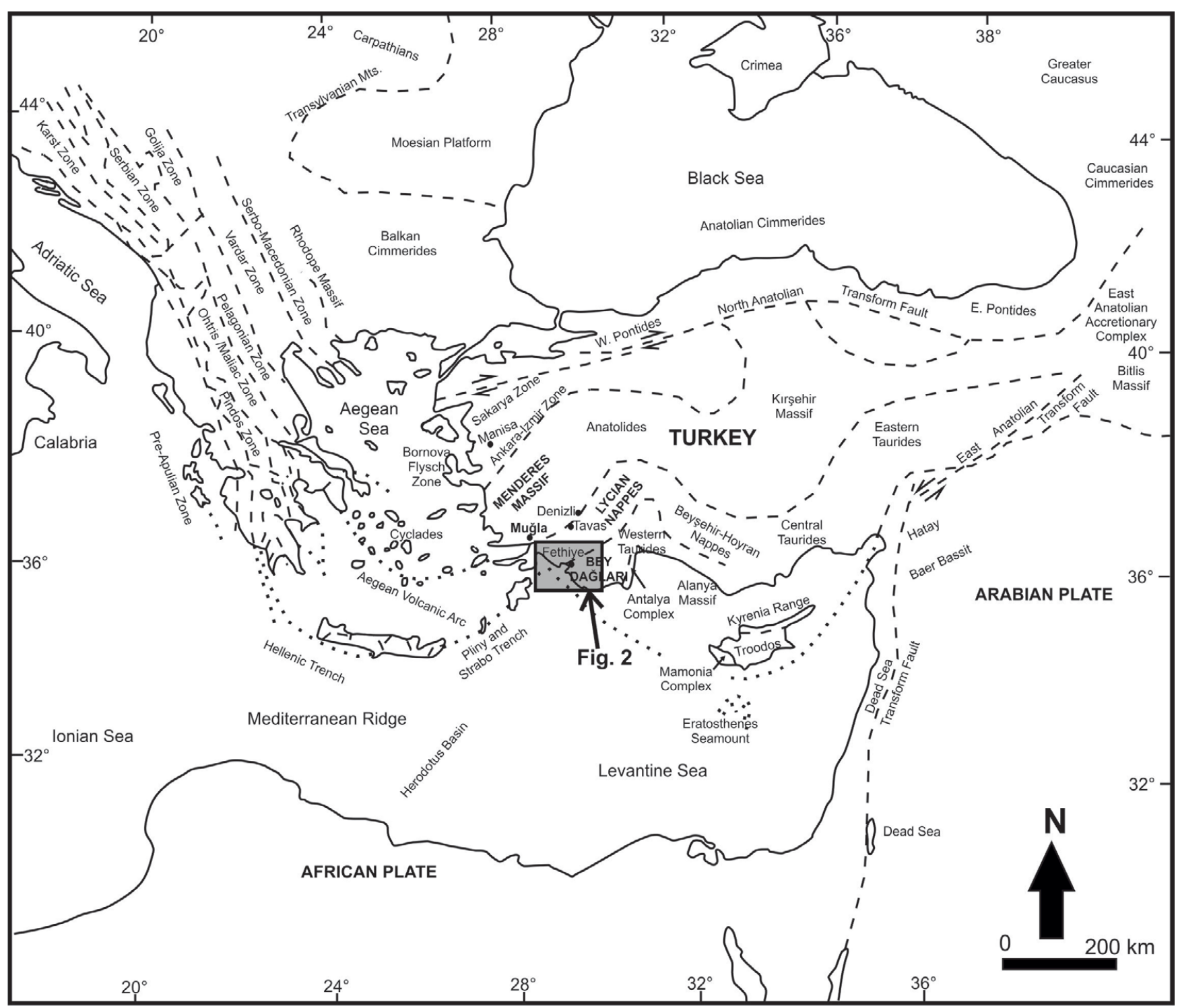

Figure 1. A location map of the study area, and main tectonic units and structural lines of the Eastern Mediterranean (modified from ROBERTSON \& DIXON, 1996). 


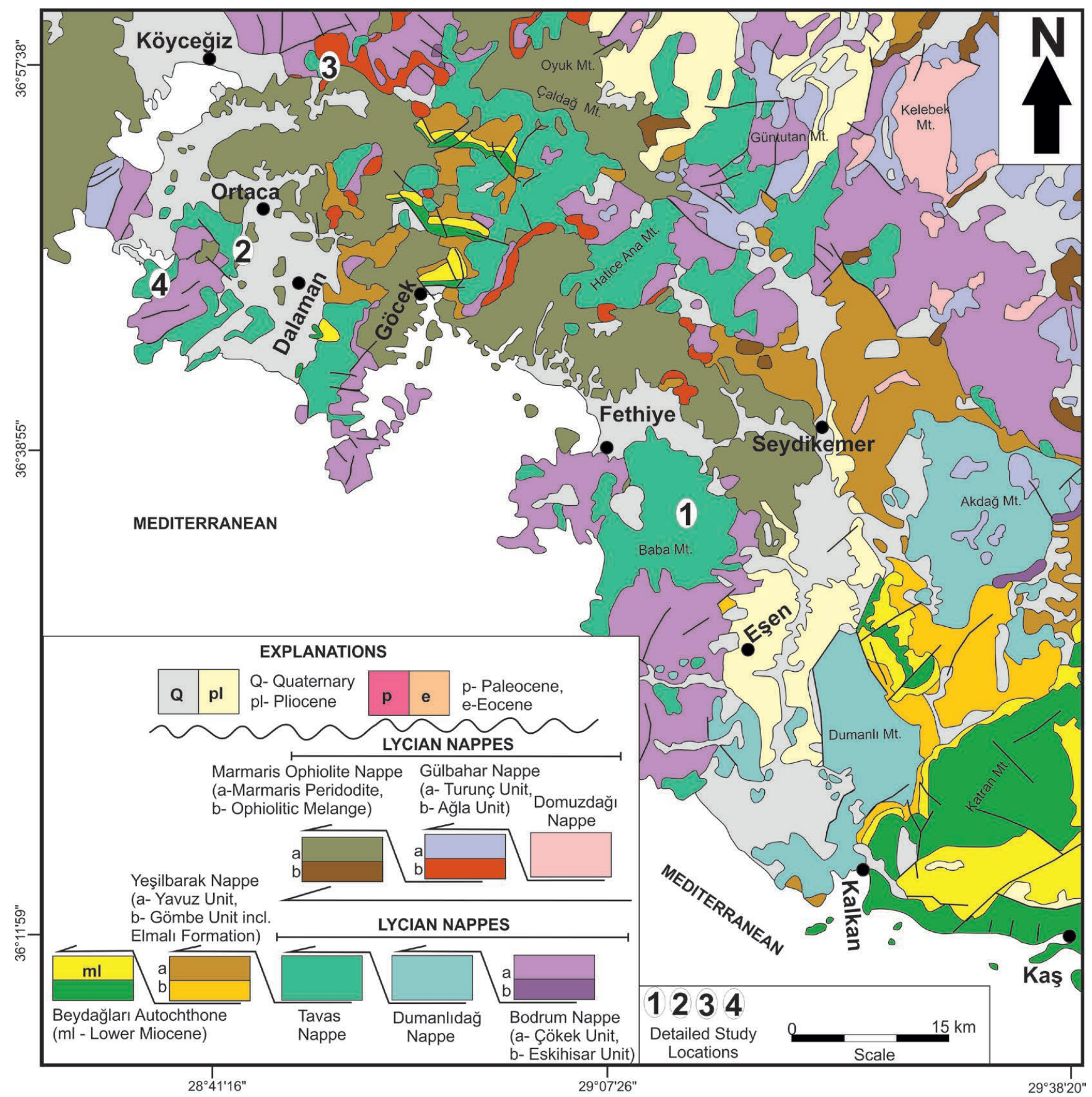

Figure 2. The tectonic units of the study area, and location of the measured stratigraphic sections (1: Babadağ sections locations, 2: Karadon sections locations, 3: Yangı section location) and detailed observation place (4: Bozburun hill location) (modified from ŞENEL, et al., 1989, 1994; ŞENEL, 1997a, 1997b, 1997c).

phibolite-schist-phyllite and marble (ŞENGÖR et al., 1984; CANDAN et al., 1998; BOZKURT, 2001; DORA, 2007; BOZKURT, 2004). The Lycian Nappes consist of south-imbricated nappes, investigated under different names (GRACIANSKY et al., 1967; GRACIANSKY, 1968; BRUNN et al., 1971; POISSON, 1977; YILMAZ, 1981; ERAKMAN et al., 1982; ŞENGÖR et al., 1984; TEKELİ, 1984; OKAY, 1989; ERSOY, 1990, 1991; ŞENEL et al., 1994; ŞENEL, 1997a, 1997b; KOZUR, 1998; COLLINS \& ROBERTSON, 1998, 1999, 2003; KONAK, 2003; DANELIAN et al., 2006; ŞENEL, 2004, 2007; GÖNCÜOĞLU, 2011; VACHARD \& MOIX, 2011; ÖZCAN et al., 2012; MOIX et al., 2013). ŞENEL et al. (1994) separated and mapped six main nappe sheets in the northern part of the Lycian Nappes; the Tavas Nappe, the Bodrum Nappe, the Dumanlıdağ Nappe, the Domuzdağ Nappe, the Gülbahar Nappe and the Marmaris Ophiolite Nappes (Figs. 2, 3).
The geological map (Fig. 2) reveals that the studied locations are surrounded mainly by the Çökek unit of the Bodrum Nappe, together with the Marmaris Peridotite and Ağla unit of the Gülbahar Nappe. The Çökek unit contains the Upper Triassic-Liassic shallow carbonate shelf product of the Kayaköy dolomite; the Dogger-Malm reef front dolomite-dolomitic limestones of the Sandak Formation; the Cretaceous continental slope-deep sea basin products of calciturbidites and cherty micrites of the Göçgediği Formation; and the Upper Senonian flysch and limestone-bearing Karaböğürtlen Formation deposited under variable deep sea basin conditions. The Ağla Unit includes the Middle-Upper Triassic mafic volcanics, radiolarites and cherty limestone deposited in the deep sea environment. The Marmaris Peridotite is composed of the Lower Cretaceous harzburgite, gabbro and diabase (Figs. 2, 3; ŞENEL, 1997a, 1997b, 2004, 2007; SOYCAN et al., 2015). 

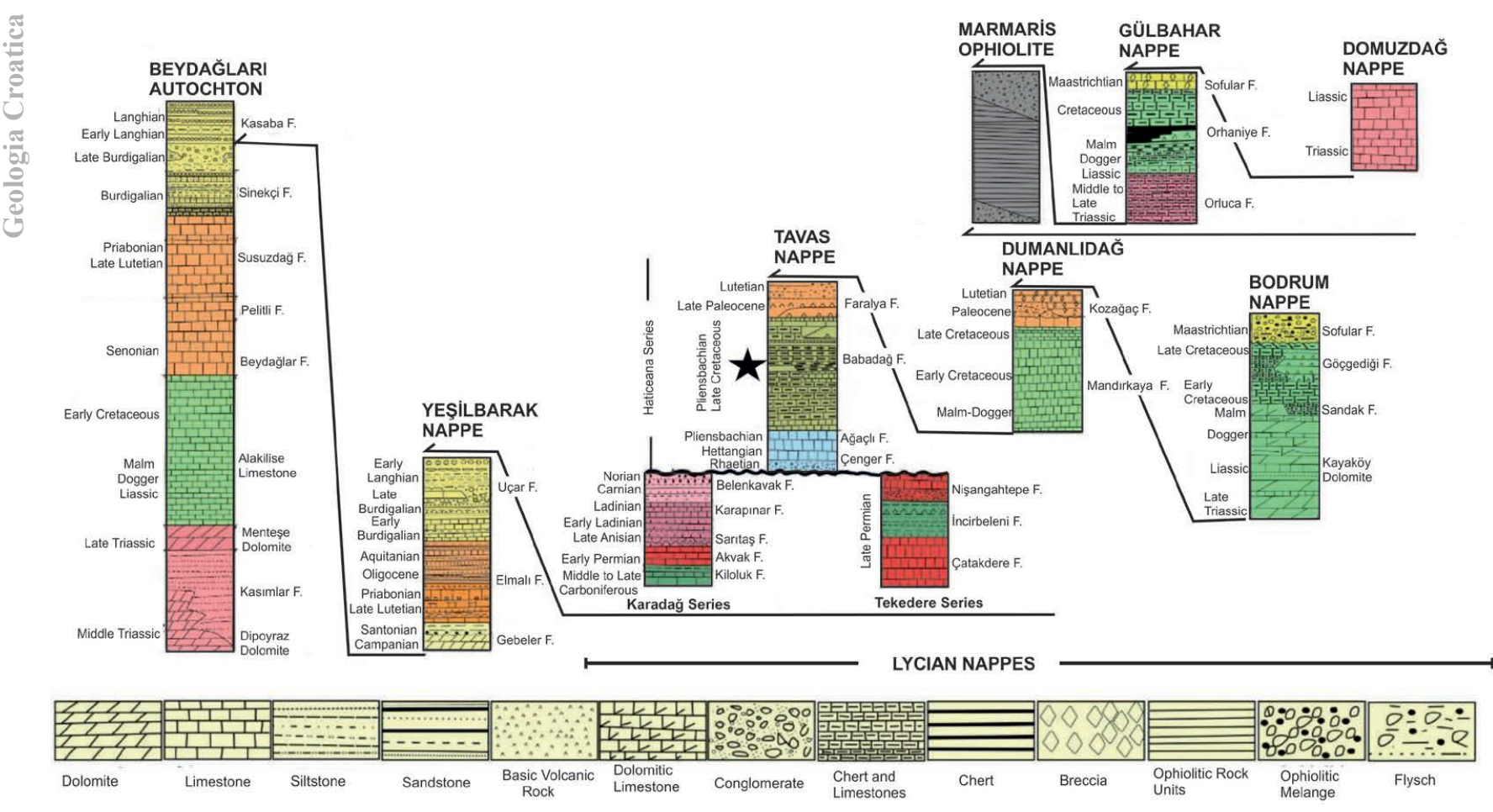

Figure 3. Allochthonous and autochthonous units in the western Taurides (F: Formation; Black Star: studied formation; after ŞENEL et al., 1997a; SOYCAN et al. 2015).

The Tavas Nappe (Triassic-Eocene) unconformably overlies the Karadağ Series (Carboniferous-Triassic limestone, dolomite and dolomitic limestone; quartz sandstone; shale) and the Tekedere Series (Upper Permian recrystallized limestones, volcanic and bedded chert interbedded green sandstone, limestone, dolomite and dolomitic limestone); and tectonically overlies the Yeşilbarak Nappe (Upper Cretaceous limestone, Eocene clastics and limestone and Lower Miocene clastics and limestone), (Figs.. 2, 3; ŞENEL et al., 1994; ŞENEL, 1997a, 1997b, 1997c, 2004). The Tavas Nappe from bottom to top is characterized by rock assemblages of the Rhaetian-Lower Liassic sandstone, conglomerate and mudstone of the Çenger Formation deposited initially in the continental (fluvial and fan) and later shore-backshore environment; the Liassic algae, coral bearing limestone, and dolomitic limestone with chert micrites, chert and shale bearing Ağaçlı Formation (a product of the stable shallow carbonate shelf); the Toarcian-Maastrichtian limestones-calciturbidites of the Babadağ Formation deposited in the continental slope and basin; and the Upper Palaeocene-Middle Eocene mafic volcanics, micrite, breccia, and sandstone of the Faralya Formation (products of variable depositional environment conditions), (Fig. 3; ŞENEL, 1997a, 1997b; ȘENEL, 2007).

A Middle Jurassic age was proposed for the lower parts of the Babadağ Formation from radiolarians, benthic foraminifera in Tavas town (NW of the study area, Fig. 1; SOYCAN et al., 2009, 2011, 2015). In and around the towns of Fethiye and Köyceğiz (Fig. 2), the Babadağ Formation contains a Red Micritic Member at the base (including Ammonitico-rosso facies, locally breccia and chert, with the age of the member reported as Upper Toarcian), An oolite bearing Limestone member in the middle part (locally with peloid and nodular chert), has a reported age as Upper Dogger-Malm. Planktonic-benthic foraminifera and rudist fragment bearing calciturbidites, Globotruncana sp. and chert bearing micritic limestone form the upper member of the formation (ŞENEL, 1997a, 1997b). This upper member of the Babadağ
Formation including calciturbidites in Bozburun hill was studied in detail by GÜL (2015) and SARI (2017). SARI (2017) determined rudist shell fragments, benthic foraminifera (Orbitoidae) and rare gastropods (denoting the Late Maastrichtian) in the uppermost part of the Bozburun hill, and defined several different forms of Globotruncana sp. from foraminiferal bearing wackestones in the lower part (designated as being of Late CampanianLate Maastrichtian age).

\section{MATERIALS AND METHODS}

Four locations were selected in an attempt to achieve the objectives of this study depending on forestry-maquis cover, road access and exposure quality. A total of six sedimentary sections were measured at three different locations on Babadağ Mountain (Babadağ-1, 50m; Babadağ-2, $120 \mathrm{~m}$; Babadağ-3, $100 \mathrm{~m}$; location 1 in Figs. 2, 4a), Ortaca town (Karadon-1, 30 m; Karadon-2, 20 $\mathrm{m}$; location 2 in Figs. 2, 4b) and Yang1 Village (Yang1 section, 170 $\mathrm{m}$; location 3 in Figs. 2, 4c). The Bozburun hill area is another study location (location 4 in Fig. 2). This region has already been documented in previous studies (GÜL et al., 2013; GÜL, 2015; SARI, 2017) due to its visible exposures in the field; however, the sedimentary textures, structures, and lateral and vertical facies changes have not been previously documented. Based on lithological variations, sampling was carried out at $1-2 \mathrm{~m}$ intervals for mineralogical, chemical and petrographic analyses. A total of ninety-nine samples were collected during the field studies (22 from the Babadağ Sections; 40 from the Karadon Sections; 23 from the Yang1 Section, 14 from the Bozburun hill region); eighty-four thin sections (22 from the Babadağ Sections; 26 from the Karadon Sections; 22 from the Yang1 Section, 14 from the Bozburun hill region) were prepared in the Thin Section Preparation Laboratories at the General Directorate of Mineral Research and Exploration (MTA, Ankara, Turkey). The thin sections were examined under binocular petrographic microscopes and the grain-size of the calciturbidites was determined at the 
Department of Geological Engineering at Muğla Sitkı Koçman University.

In this study we preferred to use the terms calcilutite (clay size), calcisiltite (silt size), calcarenite (sand size) and calcirudite (gravel size) to classify the calciturbidites in terms of the known grain sizes proposed by previous studies (GRABAUA, 1904; UDDEN, 1914; WENTWORTH, 1922; FOLK, 1980; FLÜGEL, 2004). A combined classification scheme of FOLK (1962), DUN-
HAM (1962) and EMBRY \& KLOVAN (1971) was followed for carbonate rocks. The classification of FLÜGEL (2004) was used to differentiate the samples according to the proposed Standard Microfacies Classification (SMF) to understand the depositional characteristics (PRICE, 1977; WATTS, 1987; REIJMER et al., 2008, 2012; HAAS et al., 2010; RUBERT et al., 2012).

The mineralogical compositions of the samples were determined by the X-ray diffraction method. Thirty representative sam-
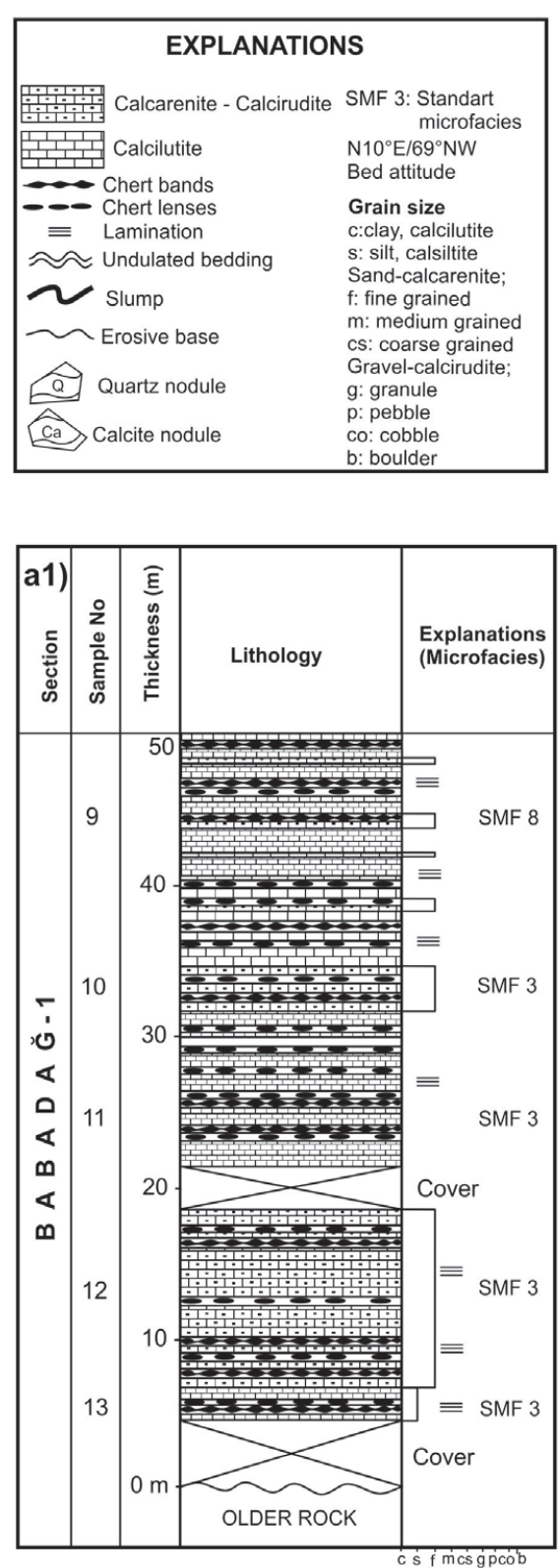
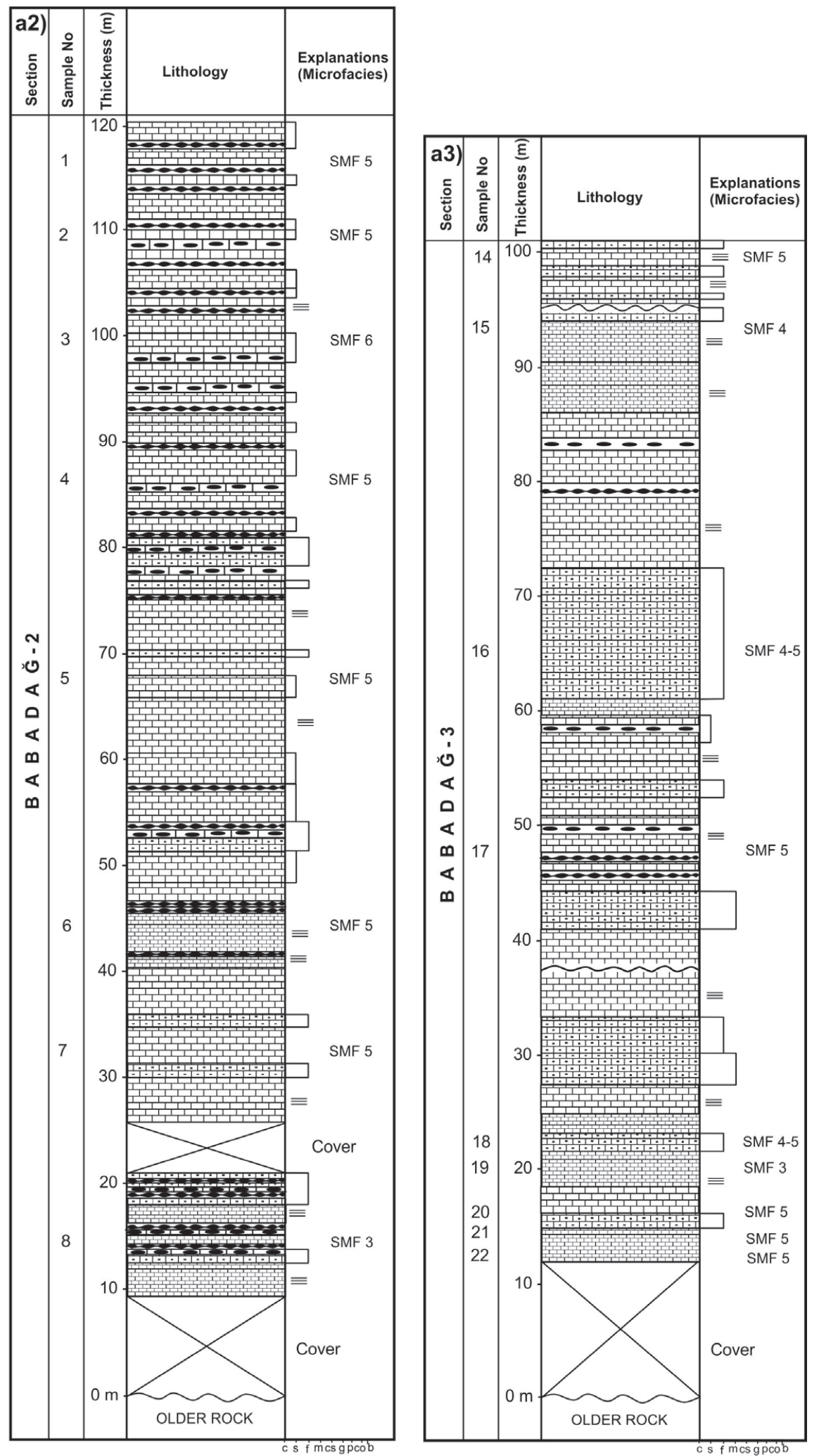

Figure 4. Measured sedimentary logs of calciturbidites (a) Babadağ sections (a1, a2, a3), (b) Karadon sections (b1, b2), (c) Yangı Section. 


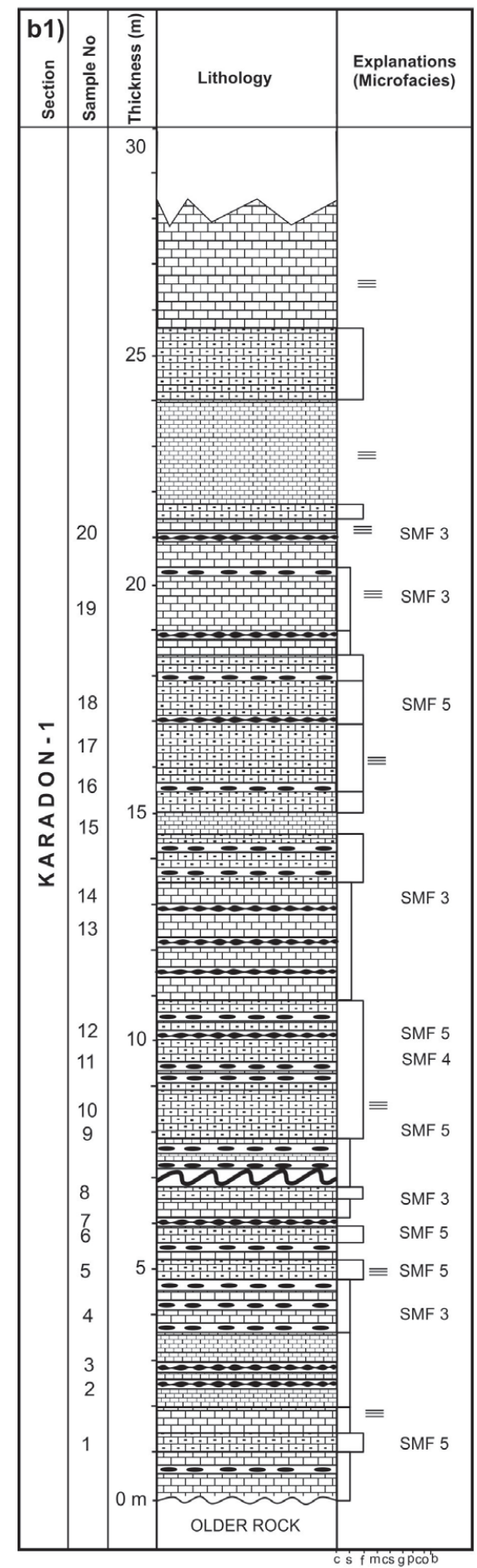

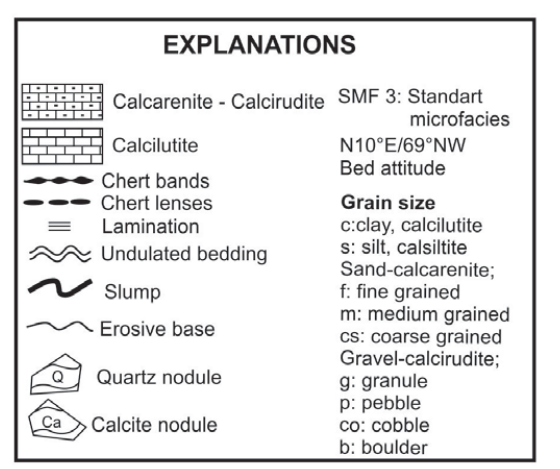

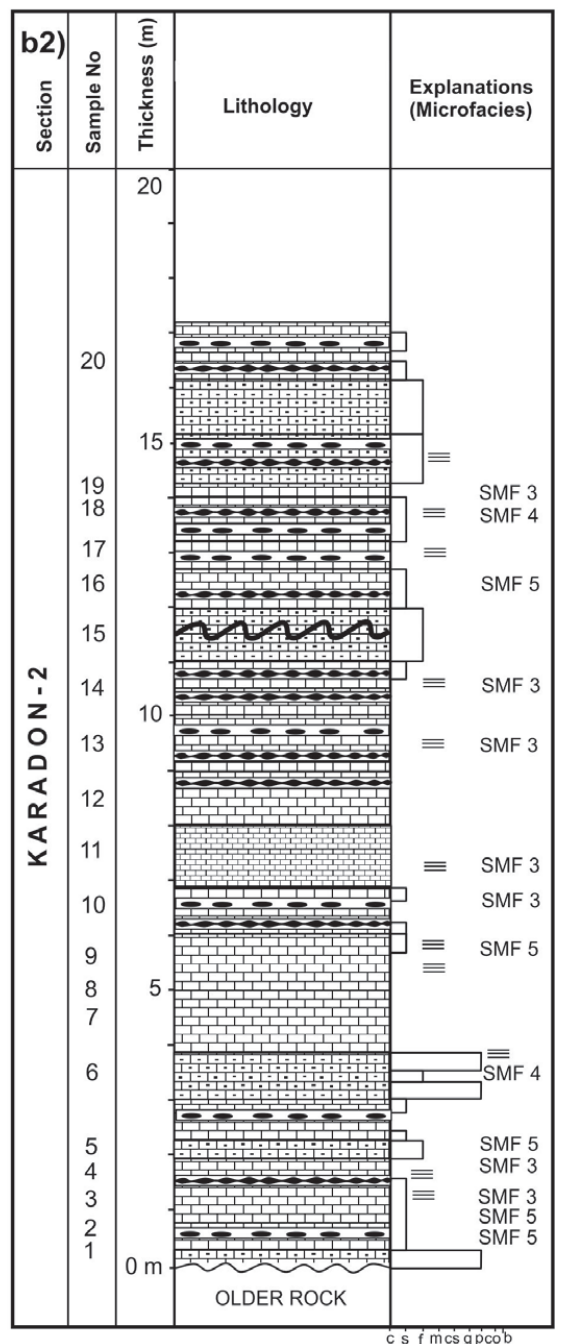

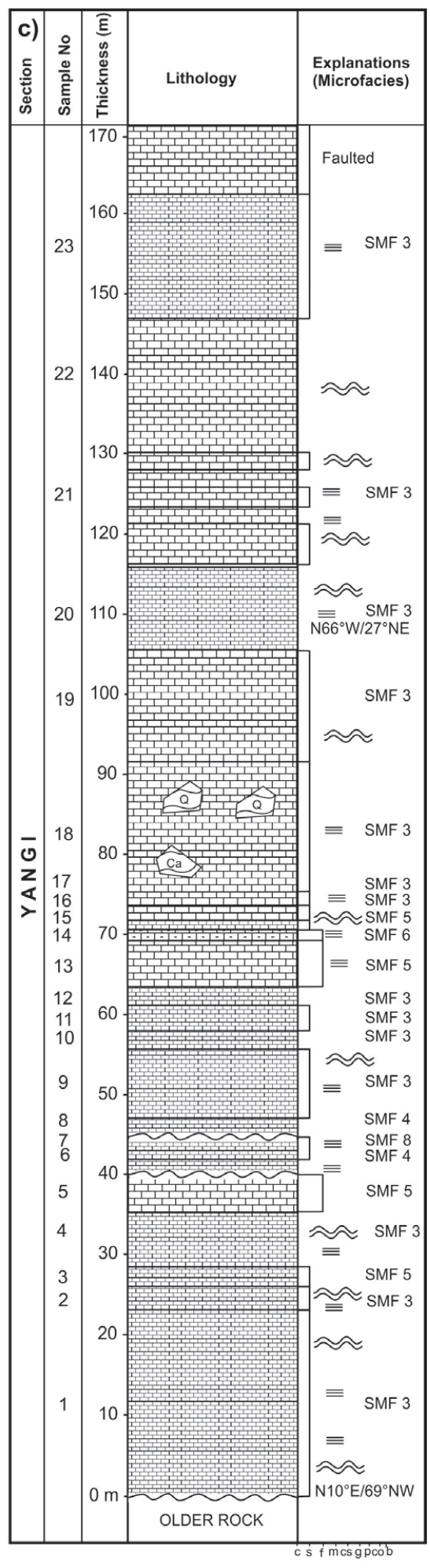

Figure 4. Continued.

ples of calcilutites and fine-grained calcarenites (nine from the Babadağ Sections; eleven from the Karadon Sections; five from the Yang1 Section, and five from the Bozburun hill region) were analysed by a Panalytical Expert Pro diffractometer equipped with a $\mathrm{Cu}$ tube at $40 \mathrm{kV}$ voltage and $30 \mathrm{~mA}$ current with a scanning rate of $2 \%$ min at the Mineralogy-Petrography Laboratory at the General Directorate of Mineral Research and Exploration (Ankara, Turkey).

$\mathrm{X}$-ray fluorescence analysis was performed to determine the major oxide compositions of 30 calciturbidite samples. GÜL (2015) stated that microcrystalline-cryptocrystalline cherts are present in the calciturbidite levels, however he did not address their diagenetic properties and textures. SEM-EDS analyses through cross-sections were carried out at the Research and Application Centre for Research Laboratories at Muğla Sitkı Koçman University (Muğla, Turkey). The specimens were sputter coated with gold (Emitech K550X Sputter Coating Systems). Samples were examined under a scanning electron microscope (SEM) (Jeol JSM-7600F, Japan) at an accelerating voltage of $15 \mathrm{kV}$. Elemental characterizations of the samples were done using the SEM equipped with Energy Dispersive X-ray Spectrometry (EDS-Oxford Instrument). 


\section{RESULTS}

\subsection{Lithostratigraphy of the Babadağ Formation}

This study focuses on the calciturbidites of the Babadağ Formation and its lithological features. The Babadağ Formation is composed mainly of calcilutite, calcisiltite, in some parts calcarenite and rarely calcirudite in its upper parts (SENEL, 1997a, 1997b; GÜL, 2015; SARI, 2017).

Babadă Sections: These sections were measured at Babadağ Mountain, which is located at 5-6 km south west of Fethiye Town (Fig. 2). In this region, the Babadağ formation conformably overlies the Ağaçlı Formation and is overlain by the
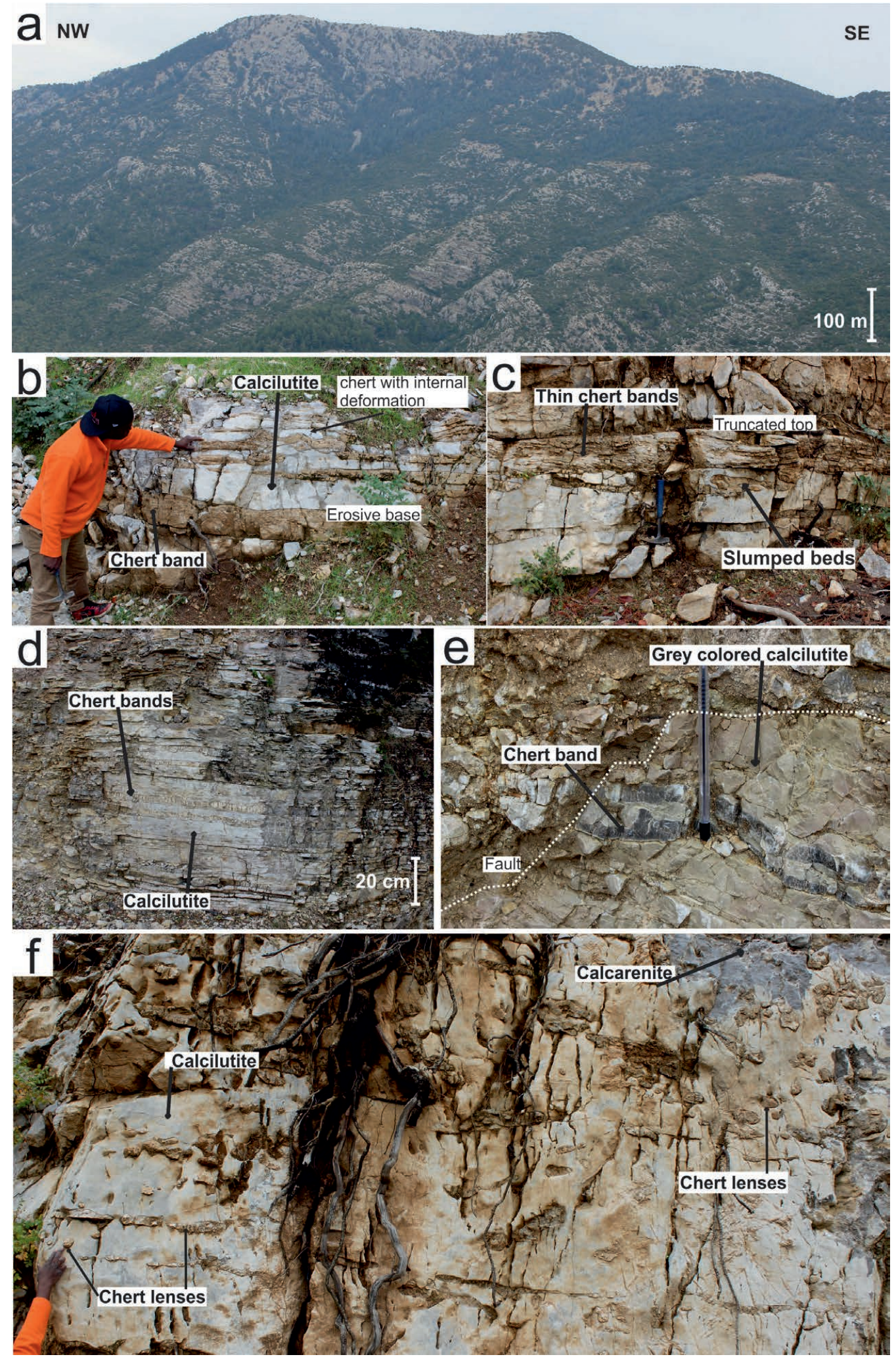

Figure 5. Field photographs showing the lithological properties of calciturbidites in several stratigraphic levels of the Babadağ sections. (a) General view of calciturbidites in Babadağ. (b) thick bedded calcilutite with chert bands, (c) grey-coloured, thin bedded calcilutite, (d) dark-grey, thin bedded calcarenite, (e) thin bedded calcarenite cut by fault, (dotted line shows the boundary between the deformed and undeformed parts of the calcarenite) (f) grey coloured, thick bedded calcilutite with chert bands. 

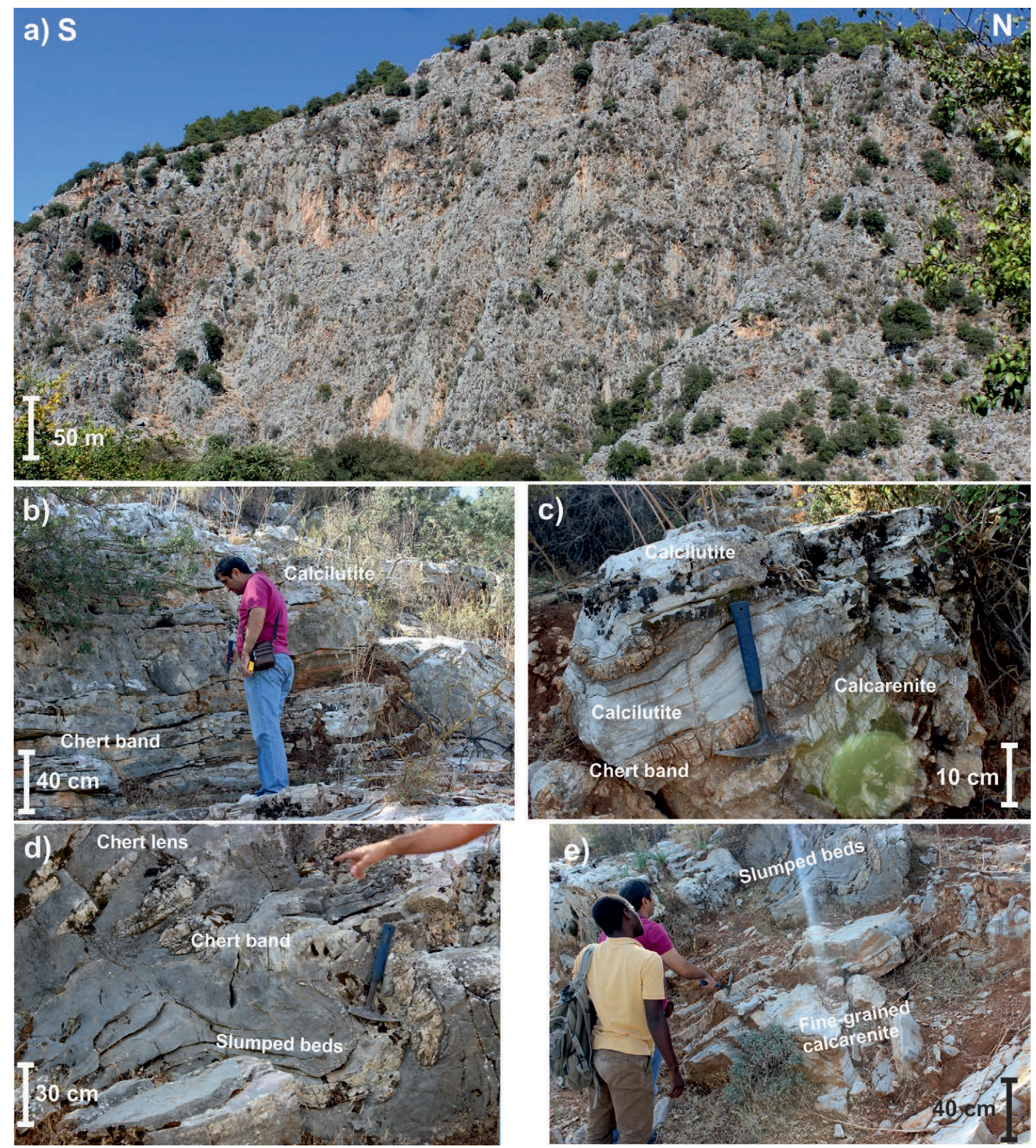

Figure 6. Field photographs showing the calciturbidites in Karadon sections. (a) General view of calciturbidites in Karadon area, (b) pinkish-grey calcilutite with chert bands, (c) reddish-grey, fine-grained calcarenite with chert-bands, (d) thick bedded calcilutite with chert-band, (e) fine-grained calcarenite with slumped chert.

Faralya Formation (Fig. 3). In addition, some levels of the Babadağ Formation are tectonically overlain by the Bodrum Nappe. The large part of Babadağ Mt. is covered with forests, making it difficult to find a straight section to measure (Fig. 4a). Some exposures were difficult to reach due to lack of proper roads and the risk of rock falls. Observations showed that the unit was faulted, folded, overturned, and highly deformed. Stratigraphic sections were measured from the possible top point of the Babadağ Mountain, through the pathways opened for Babadağ paragliding centre.

The Babadağ-1 section (50 m) measured (Fig. 4al) at the upper part is considered to be the youngest part of the Babadağ Formation (Fig. 5). The Babadağ-2 section (120 m) (Fig. 4a2) was measured in the faulted and folded middle part of the Babadağ Formation. The Babadağ-3 section (100 m) (Fig. 4a3) was mea- sured in the lowermost part of the formation. The Babadağ-1 and Babadağ-2 sections were formed by the alternations of pink-grey, thin $(3-5 \mathrm{~cm})-$ medium $(15-20 \mathrm{~cm})$ thick bedded $(30-40 \mathrm{~cm})$, erosive based, truncated topped, calcilutite-calcarenite units in places. Thin-layered $(2-3 \mathrm{~cm})$, locally slumped, chert bands and lenses are observed at the base of the unit, however they are mostly absent in the upper levels. Moreover, the Babadağ-3 section contains thin bedded $(2-5 \mathrm{~cm})$ calcilutite and thin to medium bedded $(4-15 \mathrm{~cm})$ calcarenite alternation with chert bands (3-5 $\mathrm{cm}$ thick, 5-20 $\mathrm{m}$ long) and lenses (5-10 cm thick, 30-50 cm long) (Fig. 4a; KORE, 2018).

Karadon Sections: The Karadon Sections are located to the NW of Dalaman Town (Fig. 2). Calciturbidite layers are exposed along the road cut to the south of Ortaca town. The Babadağ Formation is normally faulted in the eastern part and covered with 

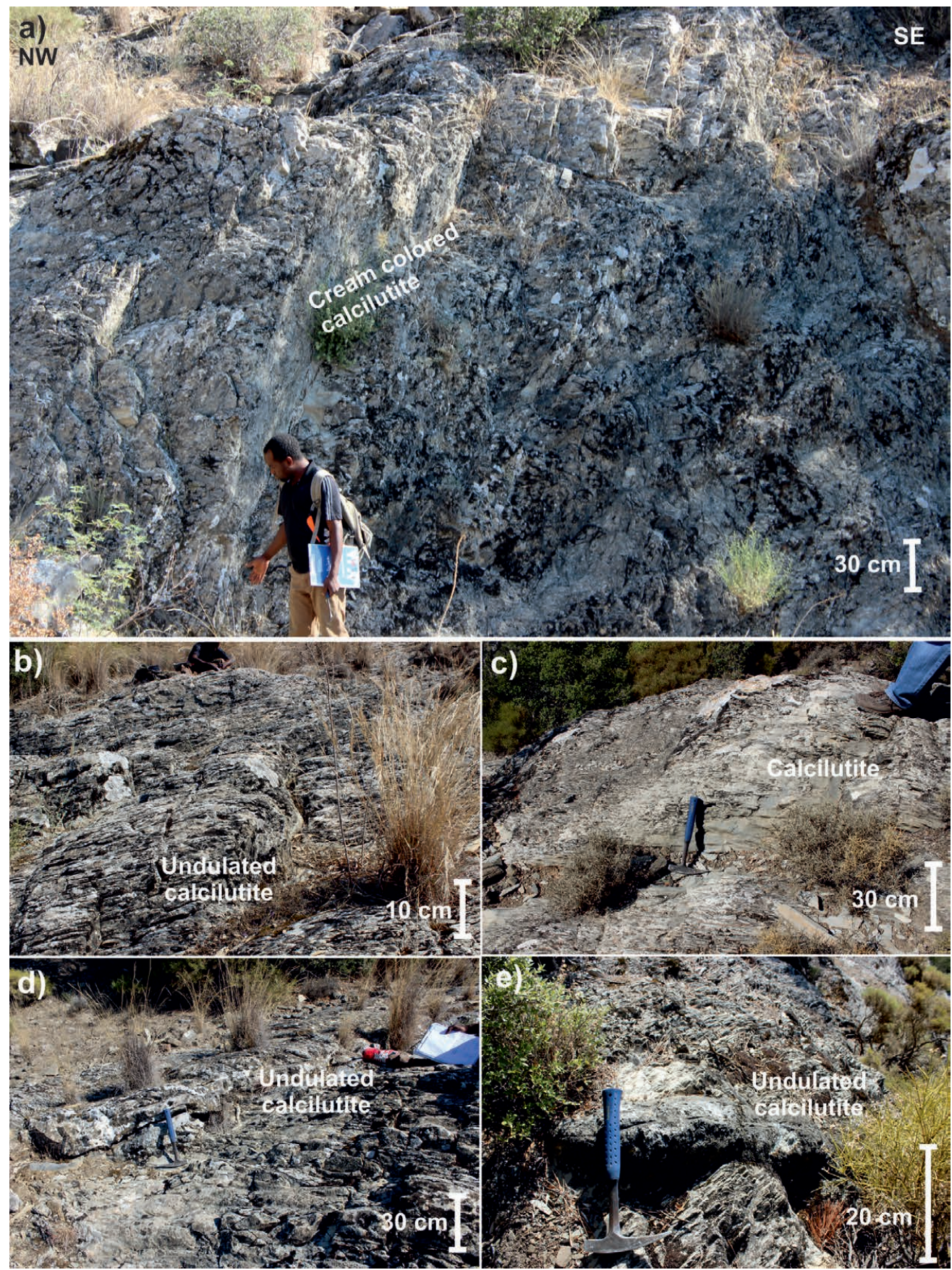

Figure 7. Field photographs showing the calciturbidites in the Yangı section; (a) General view of calciturbidites in the Yangı section, (b) grey coloured calcilutite, (c) yellow, laminated, thin bedded calcilutite, (d) undulating, thin bedded calcilutite, (e) yellow, pink coloured undulating bedded calcilutite.

alluvium. Within the Karadon neighbourhood, the Marmaris Ophiolite Nappe tectonically overlies the unit, while the Faralya Formation consisting of volcanic rocks and young sediments unconformably overlies the unit in the western part.

The Karadon-1 section is 29 m thick (Figs. 4b1, 6). At the base, there are sub-levels of highly broken-fragmented calciturbidites. The next $4 \mathrm{~m}$ consists of thin bedded $(2-7 \mathrm{~cm})$ calcilutites intercalated with thin to medium bedded $(2-15 \mathrm{~cm})$ calcarenite (Fig. 4b1). The subsequent 17 metres (between $4 \mathrm{~m}$ and $21 \mathrm{~m}$ ) contains alternations of pinkish grey, laminated to thinly $(2-5 \mathrm{~cm})$ undulating bedded calcilutite- thin to medium bedded $(2-15 \mathrm{~cm})$ undulating calcarenite, as well as slumped, red-grey chert bands (3-10 cm thick, 3-15 m long) and lenses (5-30 cm thick, $15 \mathrm{~cm}-2$ $\mathrm{m}$ long) (Figs. 6b-6e). The next 8 metres contains laminated to thinly bedded $(2-5 \mathrm{~cm})$ calcilutite and thin to medium bedded $(2-$
$15 \mathrm{~cm}$ ) calcarenite layers without chert (Fig. 4b1). The Karadon-2 section was measured from the southern wing of the small fold that contains pinkish-grey coloured, laminated to thinly bedded (2-5 $\mathrm{cm}$ thick), locally undulating calcilutite and thin to medium $(2-15 \mathrm{~cm})$ locally undulating bedded and slumped calcarenite and calcirudite, red-grey chert bands (1-10 cm thick, 7-15 m long) and lenses (3-10 cm thick, $30 \mathrm{~cm}-2 \mathrm{~m}$ long) (Fig. 4b2).

Yangl section: This section was measured in Yang1 village about 2-3 km northeast of Köyceğiz (Fig. 2). A $170 \mathrm{~m}$ thick calciturbidite succession was measured. The Yang1 section is composed predominantly of thin $(2-5 \mathrm{~cm})$-medium-thick $(10-17 \mathrm{~cm})$ bedded, undulating, cream-yellow-grey-reddish coloured laminated calcilutite, laminated calcisiltite and fine-grained calcarenite (Figs. 4c, 7). Large chert nodules were observed near to the middle of the unit. Unlike the chert observed in other areas, these were 


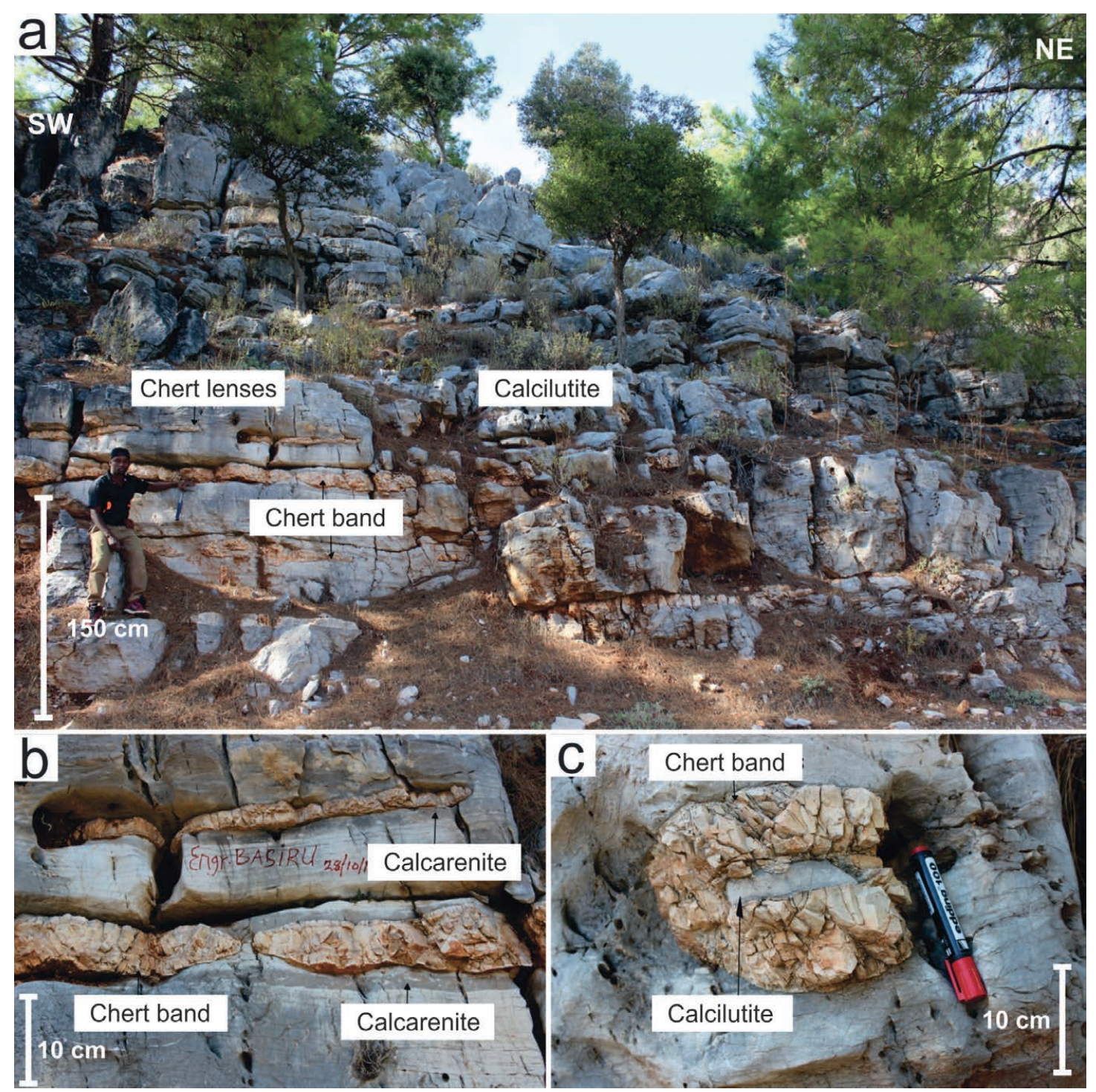

Figure 8. Field photographs showing the calciturbidites in Bozburun hill; (a) General view of calciturbidites in Bozburun hill; (b) thick bedded layered calcilutite with abundant chert bands and lenses; (c) calcilutite with chert lenses.

found to be irregularly shaped (20-30 cm thick, 1-3 m long). A slump was identified at 110 metres in the section (Fig. 7).

Bozburun hill: Bozburun hill is located on a different nappe slice, about $10 \mathrm{~km}$ southwest of the Karadon Section. On the Bozburun hill, calciturbidites of the Babadağ Formation overlie the older Tavas Nappe deposits, and are unconformably overlain by the Faralya Formation. The Bozburun hill was previously studied in detail (GÜL et al., 2013; GÜL, 2015; SARI, 2017). They reported that Bozburun hill is composed of mainly laminated and thinly $(2-5 \mathrm{~cm})$ undulating, bedded calcilutite at the base, laminated, thin $(4-8 \mathrm{~cm})$ to medium $(10-25 \mathrm{~cm})$ bedded calcarenitemainly laminated and thinly $(2-5 \mathrm{~cm})$ undulating, bedded calcilutite alternations with chert layers in the middle, while thin (4-8 $\mathrm{cm})$ to medium $(10-25 \mathrm{~cm})$ bedded calcarenites- medium $(10-25$ $\mathrm{cm})$ to thickly $(30-100 \mathrm{~cm})$ bedded calcirudites dominate the uppermost part of the succession (Fig. 8).

\subsection{Petrography and compositional changes}

Babadağ sections: A total of twenty-two samples from the Babadağ sections were examined petrographically. These samples are mainly characterized as micritic mudstone, wackestone, packstone and sparitic grainstone (DUNHAM, 1962; EMBRY \&
KLOVAN, 1971). However, there are minor occurrences of floatstones and rudstones (EMBRY \& KLOVAN, 1971).

SMF 3 (well sorted; micrite, fosiliferous micrite, mudstonewackestone; contains planktonic foraminifera, rudist shell fragments, calcite infillings through the cracks) and SMF 5 (wellmoderately-poorly sorted; packed biomicrite packstone, unsorted biosparite-grainstone; includes whole fossil and fossil fragments (rudist), calcites with perfect cleavages, large calcite infillings) type micro facies are dominant facies in Babadağ sections. SMF 4 (well-moderately-poorly sorted; packed biomicrite-wackestone, packstone; consist of fossil fragments (rudist), and calcite infillings), SMF 6 (poorly sorted; packed biomicrite, rudstone; includes rudist fossil (size $>2 \mathrm{~mm}$ and the ratio $>10 \%$ ), and calcite filling the cracks) and SMF 8 (moderately sorted; fosiliferous biomicrite, wackestone; made up of rudist fragments, and calcite infillings) are other less common components (Figs. 4, 9a, 9b). Petrographic studies reveal the presence of chert, dolomite, calcite, quartz, micrite, planktonic foraminifera and rudist fragments (Figs. 9a, 9b). The samples were interpreted as mediumthin laminated calcilutite and calcarenite. They characterize deposition in the deep sea (Facies Zone (FZ)-1), deep shelf (FZ2), toe-shelf (FZ-3), and slope (FZ-4) environments (Fig. 10). 



Figure 9. Photomicrographs of the Babadağ Formation; a) Cross polarized microview of the silicification and dolomitization of SMF-3 facies in the Babadağ Sections; b) Cross polarized microview of the relatively coarser quartz mineral replacing calcite of fossil fragments; c) Calcilutite-SMF-3 showing an undulatory contact with Calcisiltite-SMF-5. Micritization and or recrystallization may lead to this type of contact. Coarser-grained sediment transportation may also lead to an erosive contact with soft-finer-grained sediment; d) Cross polarized microview of the SMF-5 in the Karadon sections; e) Calcilutite-SMF-3 has an undulatory contact with Calcisiltite-SMF-5; f) Cross polarized view of silicification in the Yangı section; g) Microview of the SMF-3 facies in Bozburun hill; $h$ ) Intraclast and coarse-grained fossil fragments bearing SMF-5 facies in the Bozburun hill (Q: Quartz, Ch: Chert; Do: Rhombohedral dolomite; Ca: Calcite; Pl: Planktonic foraminifera). 


\begin{tabular}{|c|c|c|}
\hline & & Determined Facies Zone \\
\hline Babadağ sections & 0 & $=$ \\
\hline Karadon sections & $\mathrm{O}$ & 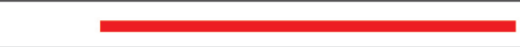 \\
\hline Yangı section & 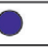 & - \\
\hline Bozburun hill samples & & 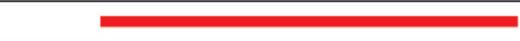 \\
\hline
\end{tabular}

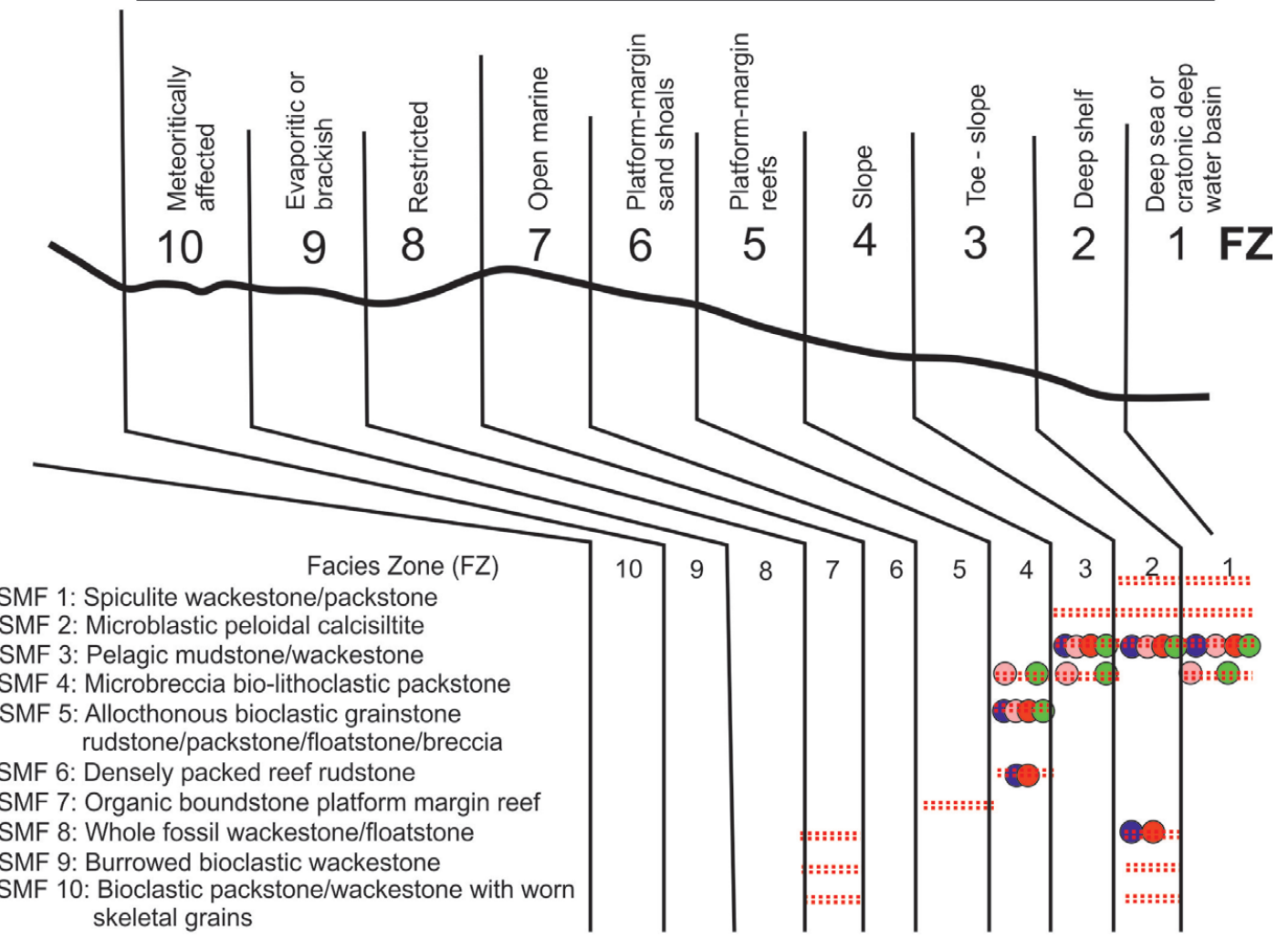

Figure 10. Standard Microfacies (SMF) and the related Facies Zone (FZ) of samples were described according to FLÜGEL (2004) classification (rimmed carbonate platform) and facies model (SMF: standard microfacies, FZ: the facies zone).

Karadon sections: Twenty-six samples from the Karadon sections were examined under the petrographic microscope (Figs. 9c, 9d, 9e). The studied samples are micritic mudstone-packstone-wackestone-bindstone, and floatstone, and sparitic grainstone (DUNHAM, 1962; EMBRY \& KLOVAN, 1971). SMF 3 (very well-well-moderately sorted; fosiliferous micrite, mudstone-wackestone; includes planktonic foraminifera, sometimes rudist fossil fragments, and calcite infillings) and SMF 5 (wellmoderately-poorly sorted; packed biomicrite, packstone, unsorted biosparite-grainstone, fosiliferous biosparite-floatstone; consist of calcite filling the fractures, whole (planktonic foraminifera) and fragments of fossil (rudist), and stylolite) type facies are the dominant facies. SMF 4 type (very poorly sorted; unsorted biomicrite, packstone; made up of silt-sand size fossil fragment-rudist) is the other less common component (Figs. 9c, 9d, 9e). They characterize the deposition in deep sea (FZ-1), deep shelf (FZ-2), toe-shelf (FZ-3), and slope (FZ-4) (Fig. 10).

Yangl section: Twenty-two samples from the Yang1 section were subjected to microscopic examination and are predominantly of micritic mudstone-floatstone (fosiliferous biomicrites) and sparitic rudstone (unsorted biosparite)-grainstone (DUNHAM, 1962; EMBRY \& KLOVAN, 1971; Figs. 4, 9f) composition. SMF 3 (well-moderately-poorly sorted; micrite, fosiliferous micrite, mudstone-wackestone; consist of whole planktonic foraminifera, rudist shell fragments, calcite infillings) is the dominant facies in the Yang1 section. SMF 5 is well-moderately-poorly sorted; packed biomicrite-packstone, unsorted biosparite-grain- stone; containing whole fossil (planktonic foraminifera) and fossil fragments (rudist), and large calcites with perfect cleavages and infillings), SMF 4 is well-poorly sorted; unsorted biomicrite, packstone; made up of silt-sand size fossil fragment, rudist. SMF 6 is very well sorted; packed biomicrite, rudstone; includes rudist fossil (their size larger than $2 \mathrm{~mm}$ and their ratio $>10 \%$ ), and calcite filling the cracks. SMF 8 (moderately-poorly sorted; fosiliferous biomicrite, wackestone-floatstone); made up of rudist fragments (size $>2 \mathrm{~mm}$ and the ratio $>10 \%$ ), calcite infillings) are other secondary components. Chert and calcite are dominant in the Yang1 section (Fig. 9f). They characterize the deposition in deep sea (FZ-1), deep shelf (FZ-2), toe-shelf (FZ-3), and slope (FZ-4) (Fig. 10).

Bozburun hill: Fourteen samples from the Bozburun hill were studied. These are dominated by micritic packstone-mudstone-wackestone with minor floatstone, and sparitic grainstone (DUNHAM, 1962; EMBRY \& KLOVAN, 1971; Figs. 9g, 9h). SMF 3 (well sorted; fosiliferous micrite, mudstone-wackestone; consist of planktonic foraminifera, rudist shell fragments, calcite infillings through the cracks) and SMF 5 (well-moderately-poorly sorted; packed biomicrite-packstone, unsorted biosparite-grainstone; contain whole fossil and fossil fragments (rudist and benthic foraminifera fragments), and large calcites with perfect cleavages filling the cracks) are the main facies types. SMF 4 type (poorly sorted; packed biomicrite-packstone; includes fossil fragments (rudist), calcite infillings) is the secondary component. Calcite, dolomite, quartz, micrites, and planktonic foraminifera 

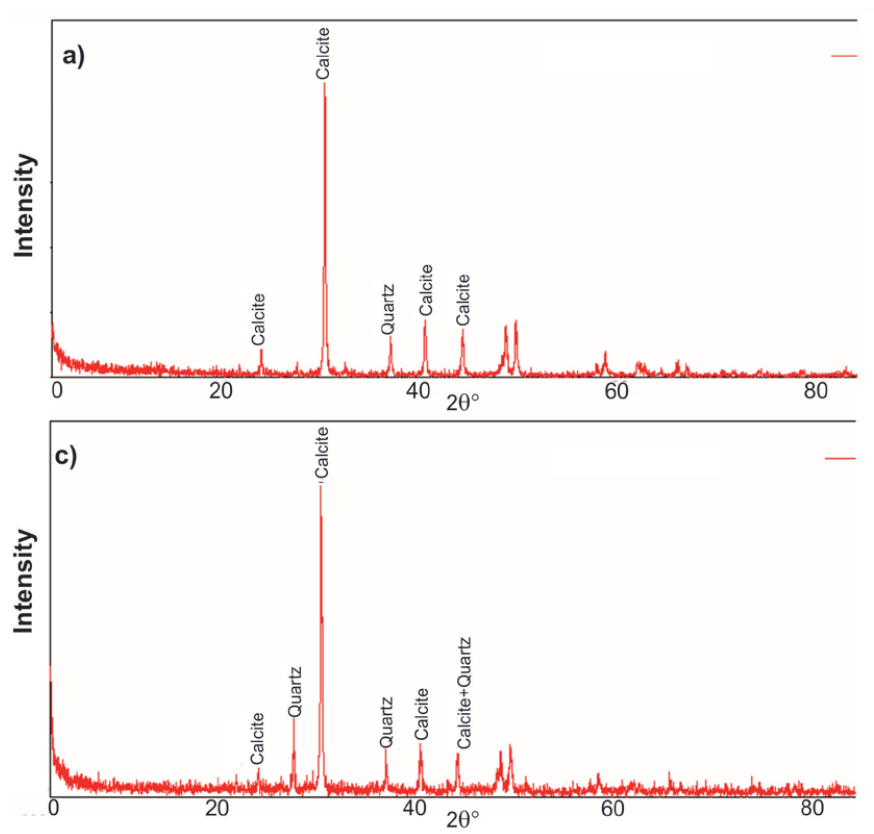
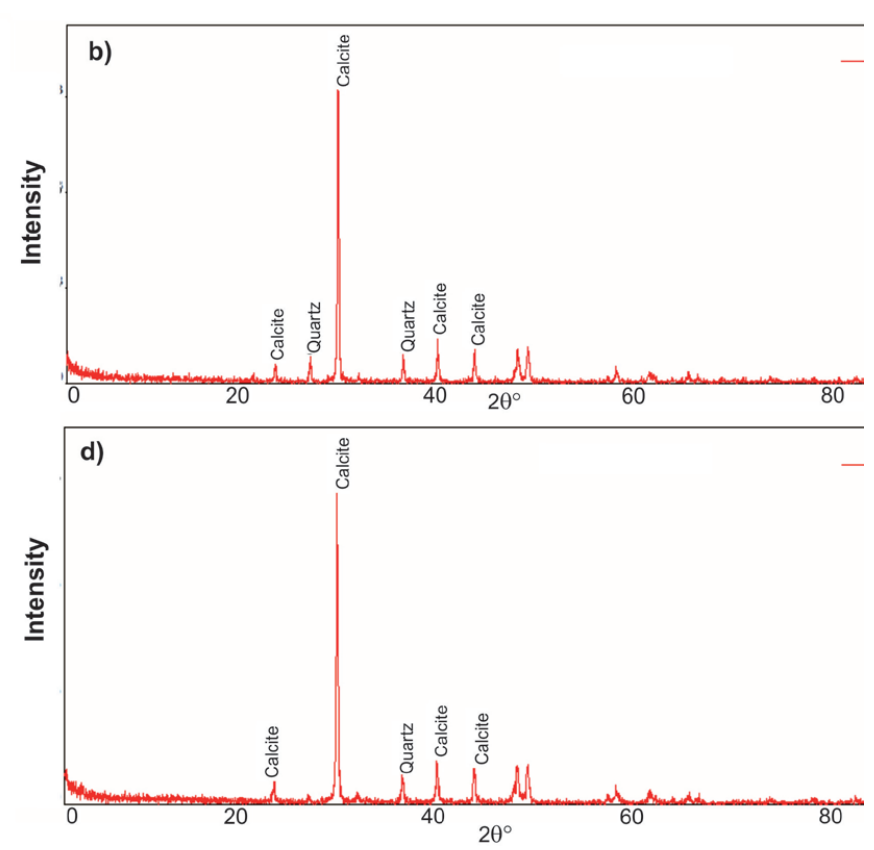

Figure 11. XRD patterns of the studied samples in (a) Babadağ sections, (b) Karadon sections, (c) Yangı section, and (d) Bozburun hill.

(SARI (2017) defines different forms of Globotruncana sp.) are common in the samples (Figs. 9g, 9h). They characterize deposition in deep sea (FZ-1), deep shelf (FZ-2), toe-shelf (FZ-3), and slope (FZ-4) (Fig. 10).

\subsection{Whole Rock Mineralogy and Geochemistry}

X-ray diffractograms reveal the dominance of quartz and calcite in all samples (Fig. 11). Quartz is observed with its prominent peak of $3.34 \AA$ at $26^{\circ} 2 \theta$; while intense reflection of calcite is determined at $29^{\circ} 2 \theta$ with $3.03 \AA$ d-spacing. Dolomite with very weak intensity at around $31^{\circ} 2 \theta$ and $2.89 \AA \mathrm{d}$-spacing is also recognized in the diffractograms (Figs. 11a, b, c, d). The mineralogical findings on the bulk compositions are consistent with the microscopic observations.

The calciturbidite layers away from the chert lenses-bands contain calcite minerals of various sizes. The regional and oneline scan-mode analysis on these layers by SEM-EDS confirms the dominance of $\mathrm{Ca}, \mathrm{C}$ and $\mathrm{O}$ as the major elements. Si amount is negligible. On the other hand, SEM-EDS analysis on the sample from Bozburun hill, close to the chert bands and lenses, points to the $\mathrm{Si}$ enrichment and $\mathrm{Ca}$ depletion, indicating the diagenetic replacement of $\mathrm{Ca}$ by $\mathrm{Si}$ (Fig. 12). Additionally, micro-cryptocrystalline calcite and quartz minerals are observed under SEM (Fig. 12 A, C, D). The EDS results are compatible with the mineral compositions (Fig. 12b). Figure 12e is the image of one-line SEM-EDS analysis which illustrates the presence of the elements $\mathrm{Si}, \mathrm{Ca}, \mathrm{Mg}$ and $\mathrm{C}$. Ca enrichment with very low Si content at the beginning of the measured line is associated with micro-cryptocrystalline calcite; whereas a higher Si content was determined towards the end of the line with negligible $\mathrm{Ca}$. Very low and almost negligible amounts of $\mathrm{Mg}$ are also recorded by EDS scan.

XRF results of the 30 samples are presented in weight percentages (wt.) in Table 1. A high purity-chert sample has more than $80 \% \mathrm{SiO}_{2}$, while calciturbidite samples away from the chertification or silicification intervals include predominantly $>50 \%$ $\mathrm{CaO}$ (Table 1). Calciturbidite samples affected by silicification contain $0.2-30 \% \mathrm{SiO}_{2}$. This inverse relationship between $\mathrm{Si}$ and $\mathrm{Ca}$ is also confirmed by SEM-EDS observations (Fig. 13). The
Babadağ, Karadon sections, and Bozburun hill samples show similar chemical compositions of very low alkali and alkaline earths. However, a few samples of the Yang1 section have two to four times higher values of the $\mathrm{Na}_{2} \mathrm{O}, \mathrm{K}_{2} \mathrm{O}, \mathrm{Al}_{2} \mathrm{O}_{3}, \mathrm{MgO}, \mathrm{TiO}_{2}$ and $\mathrm{Fe}_{2} \mathrm{O}_{3}$ values than the average values of the other sections (Table 1). LOI (Loss of Ignition Values) values are in coherence with the Ca-enriched samples (Table 1).

\section{DISCUSSION}

\subsection{Sedimentary features and related depositional environments}

The Lycian Nappes units were originally attributed to the southern part of the northern branch of the Neotethys Ocean located north of the Menderes Massif (Fig. 1) (ŞENGÖR \& YILMAZ, 1981; COLLINS \& ROBERTSON, 1998; OKAY, 2001). They migrated to the south passing over the Menderes Massif units and were emplaced between the Menderes Massif and the Beydağları Autochthone (Fig. 1; ŞENEL, 1997a; KOZUR et al., 1998; ROBERTSON, 2000; BOZKURT, 2004). The map of the TriassicCretaceous palaeogeography of the Eastern Mediterranean indicates that the northern Neotethys Ocean extended from Greece (Pelagonian Zone, Pindos Zone, Cyclades etc.) in the west to Iran in the east including the Taurides (Western Taurides, Lycian Nappes, Beyşehir-Hoyran-Hadim Nappes etc.) (Fig. 1; ROBERTSON \& DIXON, 1996; ROBERTSON \& MOUNTRAKIS, 2006; VACHARD \& MOIX, 2011). The Lycian Nappes represent a transition zone between the Greek Hellenides and the Central-Eastern Taurides-Turkey (MOIX et al., 2013). The Late Cretaceous period was represented by a compressional regime that led to the fragmentation-nappe formation and locally different depositional settings, such as carbonate platform, continental slope, and deeper marine environments in the Neotethyan Ocean (ROBERTSON \& DIXON, 1996; ROBERTSON \& MOUNTRAKIS, 2006; VACHARD \& MOIX, 2011).

The Cenomanian-Coniacian rudist bearing limestones and the Cenomanian-Campanian micritic limestone are unconformably overlain by the Campanian? - Maastrichtian units of breccia, conglomerates, carbonated sandstones (calciturbidites?) and pe- 

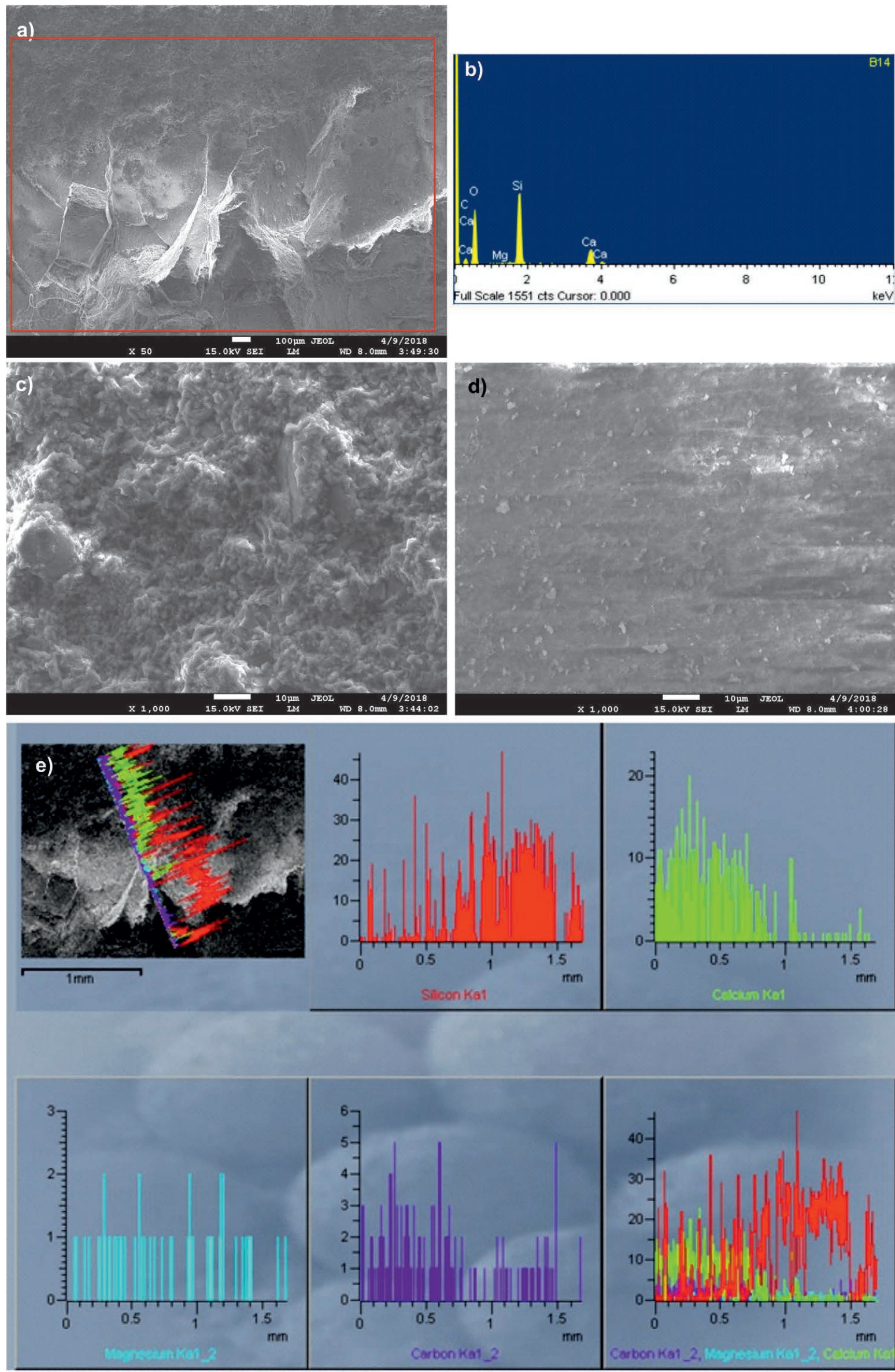

Figure 12. (a) General SEM images of sample 14 from Bozburun hill. (b) Regional EDS analysis on the red rectangle in figure A. (c) SEM view of the micro-cryptocrystalline quartz bearing chert part of figure A. (d) SEM view of the micro-cryptocrystalline calcite mineral bearing calcilutite of figure A. (e) One-line scan mode EDS analysis on sample 14 indicating an inverse relation between Si and Ca elements proving that Si replaced the Ca during the diagenesis. 
Table 1. Major oxide compositions (wt.\%) of the studied calciturbidite samples

\begin{tabular}{|c|c|c|c|c|c|c|c|c|c|c|c|}
\hline Major oxide (wt.\%) & $\mathrm{SiO}_{2}$ & $\mathrm{TiO}_{2}$ & $\mathrm{Al}_{2} \mathrm{O}_{3}$ & $\mathrm{Fe}_{2} \mathrm{O}_{3}$ & $\mathrm{MgO}$ & $\mathrm{CaO}$ & $\mathrm{Na}_{2} \mathrm{O}$ & $\mathrm{K}_{2} \mathrm{O}$ & $\mathrm{P}_{2} \mathrm{O}_{5}$ & $\mathrm{MnO}$ & LOI \\
\hline \multicolumn{12}{|l|}{ Babadağ section } \\
\hline B1 & 86.90 & 0.10 & 0.20 & 0.60 & 0.10 & 6.60 & 0.10 & $<0.10$ & $<0.10$ & 0.10 & 5.30 \\
\hline B2 & 30.40 & 0.10 & 0.10 & 0.20 & 0.30 & 37.80 & 0.10 & $<0.10$ & $<0.10$ & 0.10 & 30.90 \\
\hline B3 & 1.60 & 0.10 & 0.30 & 0.30 & 0.40 & 54.00 & 0.10 & 0.10 & $<0.10$ & 0.10 & 43.00 \\
\hline B4 & 0.50 & 0.10 & 0.20 & 0.10 & 0.40 & 54.80 & 0.10 & 0.10 & $<0.10$ & 0.10 & 43.60 \\
\hline B5 & 0.60 & 0.10 & 0.20 & 0.10 & 0.30 & 54.90 & 0.10 & $<0.10$ & $<0.10$ & 0.10 & 43.60 \\
\hline B6 & 0.40 & 0.10 & 0.10 & 0.10 & 0.40 & 54.90 & 0.10 & $<0.10$ & $<0.10$ & 0.10 & 43.80 \\
\hline B7 & 0.70 & 0.10 & 0.10 & 0.10 & 0.30 & 55.00 & 0.10 & $<0.10$ & $<0.10$ & 0.10 & 43.50 \\
\hline B8 & 0.20 & 0.10 & 0.20 & 0.10 & 0.30 & 54.80 & 0.10 & $<0.10$ & $<0.10$ & 0.10 & 44.10 \\
\hline B9 & 18.40 & 0.10 & 0.10 & 0.10 & 0.40 & 55.00 & 0.10 & $<0.10$ & $<0.10$ & 0.10 & 25.70 \\
\hline Average & 15.52 & 0.10 & 0.17 & 0.19 & 0.32 & 47.53 & 0.10 & $<0.10$ & $<0.10$ & 0.10 & 35.94 \\
\hline \multicolumn{12}{|l|}{ Karadon section } \\
\hline K1 & 0.60 & 0.10 & 0.10 & 0.10 & 0.30 & 54.90 & 0.10 & $<0.10$ & $<0.10$ & 0.10 & 43.70 \\
\hline $\mathrm{K} 2$ & 2.00 & 0.10 & 0.20 & 0.10 & 0.30 & 54.20 & 0.10 & $<0.10$ & $<0.10$ & 0.10 & 42.90 \\
\hline K3 & 22.20 & 0.10 & 0.50 & 0.20 & 0.30 & 42.20 & 0.10 & 0.10 & $<0.10$ & 0.10 & 34.20 \\
\hline K4 & 47.70 & 0.10 & 0.30 & 0.30 & 0.20 & 28.50 & 0.10 & $<0.10$ & $<0.10$ & 0.10 & 22.70 \\
\hline $\mathrm{K} 5$ & 18.30 & 0.10 & 0.20 & 0.20 & 0.30 & 44.60 & 0.10 & $<0.10$ & $<0.10$ & 0.10 & 36.10 \\
\hline K6 & 1.50 & 0.10 & 0.50 & 0.40 & 0.40 & 53.80 & 0.10 & 0.10 & 0.10 & 0.10 & 42.90 \\
\hline K7 & 0.40 & 0.10 & 0.10 & 0.10 & 0.30 & 55.10 & 0.10 & 0.10 & 0.10 & 0.10 & 43.50 \\
\hline K8 & 53.30 & 0.10 & 0.30 & 0.40 & 0.20 & 25.10 & 0.10 & 0.10 & 0.10 & 0.10 & 20.20 \\
\hline K9 & 0.30 & 0.10 & 0.10 & 0.10 & 0.30 & 55.00 & 0.10 & 0.10 & 0.10 & 0.10 & 43.70 \\
\hline K10 & 0.40 & 0.10 & 0.10 & 0.10 & 0.30 & 55.10 & 0.10 & 0.10 & 0.10 & 0.10 & 43.50 \\
\hline K11 & 0.40 & 0.10 & 0.10 & 0.10 & 0.30 & 55.10 & 0.10 & 0.10 & 0.10 & 0.10 & 43.50 \\
\hline Average & 13.37 & 0.10 & 0.23 & 0.19 & 0.29 & 47.60 & 0.10 & 0.10 & $<0.10$ & 0.10 & 37.90 \\
\hline \multicolumn{12}{|l|}{ Yangi section } \\
\hline $\mathrm{Y} 1$ & 18.40 & 0.20 & 5.10 & 2.20 & 1.00 & 39.00 & 0.40 & 0.90 & 0.10 & 0.10 & 32.60 \\
\hline Y2 & 18.40 & 0.20 & 5.10 & 2.10 & 1.00 & 39.10 & 0.50 & 0.90 & 0.10 & 0.10 & 32.50 \\
\hline Y3 & 18.30 & 0.20 & 4.10 & 1.80 & 0.80 & 40.10 & 0.60 & 0.60 & 0.10 & 0.10 & 33.30 \\
\hline Y4 & 0.30 & 0.10 & 0.10 & 0.10 & 0.30 & 55.10 & 0.10 & $<0.10$ & $<0.10$ & $<0.10$ & 43.90 \\
\hline Y5 & 0.30 & 0.10 & 0.10 & 0.10 & 0.30 & 55.10 & 0.10 & $<0.10$ & $<0.10$ & $<0.10$ & 43.90 \\
\hline Average & 11.14 & 0.16 & 2.90 & 1.26 & 0.68 & 45.68 & 0.34 & 0.80 & $<0.10$ & $<0.10$ & 37.24 \\
\hline \multicolumn{12}{|l|}{ Bozburun hill samples } \\
\hline $\mathrm{BH} 1$ & 0.40 & 0.10 & 0.10 & 0.10 & 0.40 & 54.80 & 0.10 & $<0.10$ & $<0.10$ & $<0.10$ & 44.00 \\
\hline $\mathrm{BH} 2$ & 0.50 & 0.10 & 0.10 & 0.20 & 0.30 & 54.80 & 0.10 & $<0.10$ & $<0.10$ & $<0.10$ & 43.90 \\
\hline $\mathrm{BH} 3$ & 0.90 & 0.10 & 0.10 & 0.20 & 0.30 & 54.80 & 0.10 & $<0.10$ & $<0.10$ & $<0.10$ & 43.50 \\
\hline $\mathrm{BH} 4$ & 0.60 & 0.10 & 0.20 & 0.10 & 0.40 & 54.60 & 0.10 & $<0.10$ & $<0.10$ & $<0.10$ & 43.90 \\
\hline $\mathrm{BH} 5$ & 0.90 & 0.10 & 0.20 & 0.10 & 0.20 & 54.70 & 0.10 & $<0.10$ & $<0.10$ & $<0.10$ & 43.70 \\
\hline Average & 0.66 & 0.10 & 0.14 & 0.14 & 0.32 & 54.74 & 0.10 & $<0.10$ & $<0.10$ & $<0.10$ & 43.80 \\
\hline
\end{tabular}

lagic limestones with Globotruncana sp. in the Bornova Flysch Zone in the Manisa-Spil Mountain on the western end of the İzmir-Ankara Zone in the northern part of the northern Neotethyan Ocean (SOLAK et al., 2015 and references therein). During the Campanian? - Maastrichtian period the platform was drowned and transformed into the outer platform and continental slope environment (SOLAK et al., 2015). Similar age data was reported for the upper part of the Babadağ Formation in the Bozburun hill area (SARI, 2017, and references therein). Similar planktonic foraminiferal content was also observed in the Babadağ Sections, the Karadon Sections and the Yang1 Section. However, there is no detailed palaeontological analysis of the fossil content. The northern Neotethyan Ocean covered large areas of the northern part of the Menderes Massif (ŞENGÖR \& YILMAZ, 1981). This ocean hosted important limestone, calciturbidite deposits, rudist reefs, and ophiolites (ŞENGÖR \& YILMAZ, 1981). Dependent on compressional regime during the Late Cretaceous, nappe slices of this ocean were transported to the south and formed the Lycian Nappes, some slices were transported to the north and formed the Bornova Flysch Zone (ŞENGÖR \& YILMAZ, 1981).
Upper Cretaceous calciturbidite deposits with rudist fragments and planktonic foraminifera were reported from the Anamas-Akseki Autochthone, the Antalya Nappes and the Alanya Nappes of the Southern branch of the Neotethys Ocean (ŞENEL et al., 1998). In the southern part of the central Taurides, within the upper levels of the Geyikdağ 1 tectonic unit, chert, brecciated sandy, micritic limestone alternations (Campanian) and then dark red coloured pelagic limestone and slumped hemipelagic limestone (Upper Campanian) of the Cehennemdere Formation were observed by KOÇ et al. (2016).

The existence of similar units was also reported from west of the study area. CLIFT \& ROBERTSON (1990) reported that the Argolis Peninsula in southern Greece contains Upper Cretaceous pelagic limestones, calciturbidites, limestone-conglomerates and slumped units in the middle of the Hellenides. SKOURTSIS-CORONEOU et al. (1995) reported that the Ionia Zone of the Hellenides in Western Greece contains the Tithonian-early Santonian pelagic limestone with chert and the Upper SantonianMaastrichtian detrital limestone with chert nodules. Similarly, LE GOFF et al. (2015) reported deformed gravity-flow deposits within the Ionia basin. The Pindos Zone in Western Greece also 


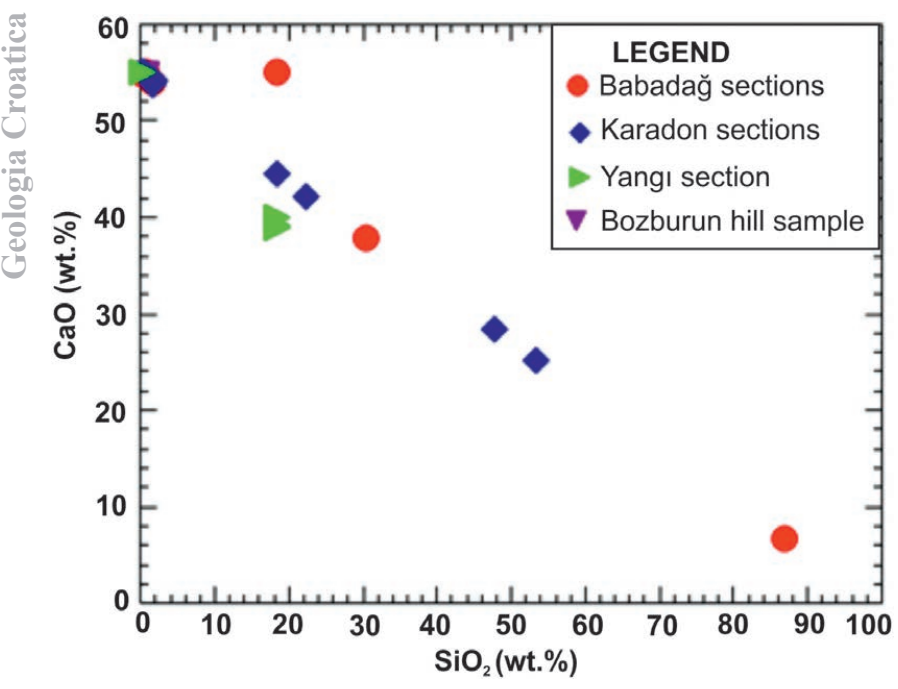

Figure 13. $\mathrm{CaO}$ versus $\mathrm{SiO}_{2}$ plot showing the inverse variation due to replacement processes during the diagenesis.

includes Lower Cretaceous radiolarite-bearing deep-sea sediments and continues with Upper Cretaceous pelagic and turbidite deposits (NEUMANN \& ZACHER, 2004).

This study reveals that the calciturbidites of the Babadag Formation include cream-grey-pink calcilutite-calcisiltite, calcarenite and calcirudite (SMF 3, 4, 5, 6, 8) with chert lenses in varying ratios. They were predominantly deposited on the slope (FZ4) to deep sea (FZ-1) environment. The highest percentage of the calcilutite (SMF 3) was determined in the Yang1 section that possibly shows the deepest depositional environment of the Babadağ Formation. Calcilutite-calcisiltite-calcarenite alternations with variable ratio in other sections indicate the impacts of local factors (sediment input, feeder mechanisms from the shelf part of the platform) in different parts of the platform. Planktonic foraminifera-bearing calcilutite requires the lowest sediment input and deposition from suspension, sand-gravel size fragments derived from the shelf margin led to the formation of calcarenite and calcirudite. The highest proportion of calcirudite at Bozburun hill may be linked with the closeness of the depositional environment to rudist buildups along the shelf margin.

The findings of the XRD, XRF, SEM-EDS and petrographic studies indicate the presence of calcite and quartz minerals in the samples. ROBERTSON \& DIXON (1996), ROBERTSON \& MOUNTRAKIS (2006), VACHARD \& MOIX (2011) and several other previous studies suggested that the calciturbidites were deposited on the carbonate platform, continental slope and deepsea environment. Detritus from the shelf included mainly calcite shelled organic buildups on the shelf margin. Thus, the sources of the calciturbidite were similar in chemical composition (dominantly $\mathrm{CaCO}_{3}$ ), with varying size (clay to gravel). The inverse relationship between $\mathrm{Si}$ and $\mathrm{Ca}$ is possibly due to silicification processes during diagenesis (Figs. 12, 13; Table 1). The presence of calcite in the mineral compositions and $\mathrm{Ca}$ in the bulk chemical composition of the chert bands and lenses indicates that the silicification process was not completed. Similarly, silica in calciturbidites reveals incomplete silicification processes. Based on petrographic observations, GÜL (2015) suggested that the quartz replacement with calcite happens without any size change. The size of the calcite minerals influences the growth of chert (Fig. 9). In figure 9a, the replacement of clay-silt sized calcite by equal size quartz led to forming, porcelainous, microcrystalline chert; while in figure $9 \mathrm{~b}$ small-medium sized quartz substitutes calcite.
Moreover, rhombohedral dolomite crystals were detected in Figure 9a. Similar observations were also reported by GÜL (2015) who determined diagenetic effects such as dolomitization, substitution-replacement, and silicification in the units based on petrographic studies.

\subsection{Factors controlling sedimentation}

The main controlling factors on the deep-sea sediments including calciturbidites are tectonic activity, sea-level fluctuation, basin morphology-geometry, sediment input, water chemistry, currents, continental slope height-gradient, organic activities, climate changes, etc. (EVERTS, 1991; READING, 1991; REIJMER et al., 1991; HAUGHTON, 1994; RICHARDS et al., 1998; HAUGHTON, 2000; ESCHARD \& JOSEPH, 2002; LOMAS \& JOSEPH, 2004; DEWEVER et al., 2007; REIJMER et al., 2008, 2012; GARCIACARO et al., 2011; GÜL et al., 2012; RUBERT et al., 2012; HAIRABIAN et al., 2015; REIJMER et al., 2015a, $2015 b)$. These factors may vary from region to region. For example; the main tectonic activities and related sea floor morphology control the sediment input and sediment quantity and thus gravity-flow deposits in the Southern Provence Basin (SE France) (REIJMER et al., 1991; SAVARY et al., 2004; REIJMER et al., 2015b). Moreover, a few $\mathrm{cm}$ thick calciturbidite layers at the base of the Lower Cretaceous cherty limestones in Slovakia in the middle of the Western Carpathians are associated with smallscale seismic activity (MICHALIK et al., 2012). Additionally, linear source formation, asymmetric geometry of base topography and facies differences of the Jurassic units in the Eastern Alpine-Swiss were attributed to a boundary fault (EBERLI, 1987). The calciturbiditic Pliensbachian (Lower Jurassic)-Upper Cretaceous series of the Lycian Nappes were interpreted as reflecting the passive continental margin period after the syn-rift period (MOIX et al., 2013). Sea level changes were responsible for excess sediment input and calciturbidite formation in the Bahamas during the Pleistocene (REIJMER et al., 2008, 2015a). Variations in the turbidity flow regime led to the development of lithologically different units such as mudstone-wackestone, sorted or packed biomicrite-packstone etc. (DEWEVER et al., 2007).

Several factors account for the deposition of the calciturbidites in the study area. Notable factors among these are discussed below.

\subsubsection{Tectonism and depositional basin geometry}

Tectonism controls the morphology-geometry of the sea floor, the amount of sediment supply, palaeocurrent direction, entry point of the sediments, sediment quantity, internal structure of the sediments including slumps and flow characteristics (energy, velocity etc. thus facies type) (BOUMA, 2004; GÜL et al., 2012; BAUMGARTNER, 2013).

The depositional environments of the Babadağ Formation were interpreted as continental slope, and related platform margin-shelf margin and deep water (ŞENEL et al., 1994; ŞENEL, 1997a, 1997b, 1997c; COLLINS \& ROBERTSON, 1998, 1999; GÜL, 2015; SOYCAN et al., 2015; SARI, 2017; Fig. 10). Seismic activities and/or sea level fluctuation triggered the destabilisation of sediments on the shelf-platform margin areas before the nappe formation and led to the formation of coarse-grain sediments (calcirudite and calcarenite) on the continental slope and toe of slope (GÜL et al., 2012, 2013; GÜL, 2015). Alternatively, tectonically quiet periods were represented by calcilutite layers. Moreover, an internal deformation (undulating bedding, slumps) of the sediments characterized the continental slope environment. Calcite- 
filled joints, folding, faulting, and nappe formation - fragmentation of the original carbonate platform was also related to tectonic activities during and after the Lycian Nappe migration.

\subsubsection{Sea level fluctuations and sea depth}

Sea level fluctuation and related sea depth control the transportation and deposition of deep-sea sediments (BOGGS, 1987; READING, 1991; GÜRBÜZ, 1999; GERVAIS et al., 2004; REIJMER et al., 2008; GÜL et al., 2011, 2012, 2015; SOYCAN et al., 2009, 2011, 2015). Sea level fluctuations cause destabilization of sediment on the shelf edge and on the continental slope (GÜRBÜZ, 1999; GERVAIS et al., 2004). GÜL et al. (2012) proposed that large scale-regional and/or possibly global sea level changes control depocenter development and large-scale sediment differentiation, moreover small-scale variation of sea level was possibly due to local tectonic activities that led to the facies variations of the Babadağ Formation. The Standard Micro Facies (SMF) changes and related Facies Zone (FZ) changes indicate that the four main depositional environments were 'slope, toe of slope, deep shelf, deep sea water basin - FZ 4-3-2-1' (Fig. 10). Sea-level fluctuations due to regional uplift and subsidence of the basin may be responsible for these environmental transitions. The falling stage and/or tectonically active period in association with excess sediment input caused the coarse-grained calcirudite-calcarenite level in the Babadağ section to represent deposition on slopeslope front environments (FZ-3-4; Fig. 10). Subsequent planktonic foraminifera bearing calcilutite levels were interpreted as a product of the highstand period, low energy level, and quiet deepsea environment (FZ-1-2; Fig. 10) conditions.

\subsubsection{Sediment input and sediment type (nature of the source area)}

Sediment entry, sediment type and sediment quantity have affected the deep-sea sediment characteristics, including geometry and facies differentiation, such as single or multiple-sourced submarine fans, coarse grained-sand rich turbidite systems and a fine grained-mud rich turbidite system depending on depocenter (RICHARDS et al., 1998; GÜRBÜZ, 1999; BOUMA, 2004; GERVAIS et al., 2004; GARCIACARO et al., 2011; GÜL et al., 2011, 2012, 2015).

Calcarenite-calcirudite levels of the Babadağ Formation were formed as a result of the sediments derived from the shelf including rudist buildups. The fragments of these initially accumulated on the shelf margin and tectonic activity/sea level lowering triggered destabilization and downslope movement. The calciruditecalcarenite (unsorted biomicrite-sparite or floatstone-rudstone) deposited on the slope and toe of slope (FZ 4, 3) depended on excess sediment input and a short transportation distance. Generally, 3-5 cm thick calcarenite and calcirudite levels were defined in the Babadağ, Karadon and Yang1 sections, while field observations during this study and GÜL et al. (2013) and GÜL (2015) documented $30 \mathrm{~cm}-2 \mathrm{~m}$ thick calcirudite levels in the Bozburun hill area, representing excess sediment input and/or close proximity to the source area. The ophiolite belts in the Eastern Mediterranean including the Neotethyan Oceans evolved from the Jurassic to the Cretaceous (ŞENGÖR \& YILMAZ, 1981; ŞENGÖR et al., 1984; ROBERTSON, 2002; ALDANMAZ et al., 2009). The emplacement age of the ophiolite was reported as Late Cretaceous (ALDANMAZ et al., 2009). Enrichment in Fe-Al-Na in the Yang1 section should be linked with the mafic-ultramafic ophiolitic rocks of the Lycian Nappes. Local sediment input from the ophiolites to the original depositional environment may have resulted in these higher values in the elemental compositions of the samples from the Yang1 Section (KORE \& GÜL, 2017; KORE, 2018).
Silicification during and after lithification led to the formation of chert nodule-bands (GÜL et al., 2013; GÜL, 2015; SARI 2017). GÜL (2015) used petrographic results to explain this process. He reported that chert horizons were mostly observed with the calcarenite-calcirudite level on Bozburun hill. In addition, he also documented that porcelainous microcrystalline quartz formed as a result of the replacement of calcilutite, chalcedony type quartz minerals were developed depending on the substitution of large calcite minerals such as rudist fragments. Elemental analysis clearly indicates the replacement between the $\mathrm{Si}$ and $\mathrm{Ca}$ elements via the inverse proportions of these two elements (KORE \& GÜL, 2017; KORE, 2018). Silicification slightly penetrated into the calciturbidites at lower and upper part of the chert bands (GÜL, 2015). Furthermore, lateral continuation of the chert bands and lenses is limited over a short distance. The longest chert bed reported by GÜL (2015) is $35 \mathrm{~m}$ in the Bozburun hill area. It is thought that the formation of chert depends on the circulation and amount of silica-rich water that penetrated the calciturbidites. Thus the permeability and porosity of the host rock (calciturbidites) were to become important factors controlling the silica rich water circulation. Thus, it is anticipated that more chert formation occurred in the calcarenites and calcirudites as in the Bozburun hill, Babadağ-1 section, Babadağ-2 section, Karadon-1 section, and Karadon-2 section (Fig. 4). In addition, if the chert beds were deposited syn-sedimentary and alternated with the calciturbidites, long and more regular chert beds could be traced. However, the irregular and short chert occurrences of the Babadağ Formation suggest that they evolved during diagenesis of the calciturbidite via quartz replacing calcite. In addition to these, post-sedimentary diagenetic activities can also be traced by rhombohedral dolomite formations within the cracks already filled by calcites that cut both calciturbidites and cherts.

This study reveals that an investigation on the distant nappe unit that is mapped under the same name, should supply the information about the original depositional environment. Detailed analysis of each nappe slice is useful for determining the local controlling factors on deposition besides the general trend confirmation. Other important issues related to calciturbidite deposition are that they are generally affected by tectonic activities and the depth of the basin. Local sediment type-size-quantity may lead to coarse-grain deposition. Calciturbidites play an active role during diagenesis, and also open pathways for chemically active liquids through which they can move easily leading to the formation of chert bands and lenses as observed in the study area.

\section{CONCLUSIONS}

This study documents the compositional changes, and discusses the factors controlling the deposition and sedimentological characteristics of the calciturbidites of the Babadağ Formation of the Tavas Nappe in Muğla (SW Turkey). With the help of field observations and many analytical methods, the following conclusions are drawn:

The studied calciturbidites comprise mainly calcilutite - calcisiltite, and calcarenite-calcirudite in a small amount depending on the environmental conditions. Calcarenite and calcirudite occurrences represent deposition on the slope or toe of slope; however, the predominance of calcilutite points to deposition in deep shelf and deep sea environments.

Planktonic foraminifera-bearing, micritic calcilutites were deposited in the deep marine-deep shelf-toe of slope environ- 
ments. Mostly rudist fragment-bearing, locally slumped-undulating bedded-deformed calcarenites and to a lesser extent calcirudites were deposited in the slope environment.

Detailed analysis of each nappe slice belonging to the same nappe unit not only provides general information on the environment and lithology, but also indicates local factors including local sediment input etc.

Tectonism and sea-level fluctuations are determined as the main controlling factors on deposition of the Babadağ Formation. Steady, tectonically quiet periods, low sediment input and the absence of gravity flows resulted in the deposition of calcilutitemicritic sediments. Subsequently, sea-level lowering, tectonically active periods (uplift) and excess sediment input led to the development of calcarenite-calcirudite levels. Changes of the controlling factors over time triggered the repetition of formation of the fine-grained and coarse-grained calciturbidites.

Sediment grain size played an important role during diagenetic stages. The coarse-grained calciturbidite supply provided a suitable pathway for Si enrichment water circulation and therefore chert or dolomite formation.

Calcite and quartz were observed as the major mineral components in the samples. Both SEM-EDS and XRF analysis show the inverse variation between $\mathrm{CaO}$ and $\mathrm{SiO}_{2}$ due to replacement during diagenesis. Excess silica replacement especially was generally observed in calcarenite-calcirudite levels which, in turn, led to formation of the chert bands/lenses. All chert bands contain a negligible amount of calcite which is due to the incomplete silicification process. Moreover, the Si content of pure calciturbidite samples either above or below the chert level shows the diffusive characteristics of the Si-enriched water.

\section{ACKNOWLEDGEMENT}

This study was financially supported by the Scientific Research Projects Office (BAP; project No. 17/118) of Muğla Sitk1 Koçman University, Turkey for the M.Sc. thesis of the first author. The authors would like to acknowledge the valuable contributions of the anonymous reviewers and editors.

\section{REFERENCES}

ALDANMAZ, E., SCHMIDT, M.W., GOURGAUD, A. \& MEISEL, T. (2009): Midocean ridge and supra-subduction geochemical signatures in spinel-peridotites from the Neotethyan ophiolites in SW Turkey: Implications for upper mantle melting processes.- Lithos, 113, 691-708. doi: 10.1016/j.lithos.2009.03.010

BAUMGARTNER, P.O. (2013): Mesozoic radiolarites - accumulation as a function of sea surface fertility on Tethyan margins and in ocean basins.- Sedimentology, 60, 292-318. doi: 10.1111/sed.12022

BEHL, R.J. (2011): Chert spheroids of the Monterey Formation, California (USA): early-diagenetic structures of bedded siliceous deposits.- Sedimentology, 58, 325-351. doi: 10.1111/j.1365-3091.2010.01165.x

BOGGS, S.JR. (1987): Principles of Sedimentology and Stratigraphy.- Macmillan Publishing Company, New York, USA, 771 p.

BOUMA, A.H. (2004): Key controls on the characteristics of turbidite systems.- In: LOMAS, S.A. \& JOSEPH, P. (eds.): Confined Turbidite Systems.- Geological Society, London, Special Publications, 222, 9-23. doi: 10.1144/GSL.SP.2004.222.01.02

BOZKURT, E. (2001): Late Alpine evolution of the central Menderes Massif, western Turkey.- Int. J. Earth Sciences, 89, 728-744. doi: 10.1007/s005310000141

BOZKURT, E. (2004): Granitoid rocks of the southern Menderes Massif (southwestern Turkey): field evidence for Tertiary magmatism in an extensional shear zone.- Int. J. Earth Sciences, 93, 52-71. doi: 10.1007/s00531-003-0369-0

BRUNN, J.H., DUMONT, J.F., GRACIANSKY, P., GUTNIC, M., JUTEAU, T., MARCOUX, J., MONOD, O. \& POISSON, A. (1971): Outline of the geology of the western Taurids.- Geology and history of Turkey, 225, $17 \mathrm{p}$.

CANDAN, O., DORA, O.Ö., OBERHÄNSLI, R., CETINKAPLAN, M., PARTZSCH, J.H., WARKUS, F.C. \& DÜRR, S. (2001): Pan-African high-pressure metamorphism in the Precambrian basement of the Menderes Massif, western Anatolia, Turkey.- Int. J. Earth Sci., 89/4, 793-811.
CLIFT, P.D. \& ROBERTSON, A.H.F. (1990): A Cretaceous Neo-Tethyan carbonate margin in Argolis southern Greece.-Geological Magazine, 127, 299-308. doi: 10.1017/ S0016756800014862.

COLLINS, A.S. \& ROBERTSON, A.H.F. (1998): Processes of Late Cretaceous to Late Miocene episodic thrust-sheet translation in the Lycian Taurides, SW Turkey.- Journal of the Geological Society, London, 155, 759-772. doi: 10.1144/gsjgs.155.5.0759

COLLINS, A.S. \& ROBERTSON, A.H.F. (1999): Evolution of the Lycian Allochthonous, western Turkey, as a north-facing Late Palaeozoic to Mesozoic rift and passive continental margin.- Geological Journal, 34, 107-138.

COLLINS, A.S. \& ROBERTSON, A.H.F. (2003): Kinematic evidence for Late Mesozoic-Miocene emplacement of the Lycian Allochthonous over the Western Anatolide Belt, SW Turkey.- Geological Journal, 38, 295-310.

DANELIAN, T., ROBERTSON, A.H.F., COLLINS, A.S. \& POISSON, A. (2006): Biochronology of Jurassic and Early Cretaceous radiolarites from the Lycian Mélange (SW Turkey) and implications for the evolution of the Northern Neotethyan ocean.In: ROBERTSON, A.H.F. \& MOUNTRAKIS, D. (eds.): Tectonic Development of the Eastern Mediterranean Region. Geological Society, London, Special Publications, 260, 229-237. doi: 10.1144/GSL.SP.2006.260.01.10

DEWEVER, B., BREESCH, L., MEZINI, A. \& SWENNEN, R. (2007): Sedimentological and marine eogenetic control on porosity distribution in Upper Cretaceous carbonate turbidites (central Albania).- Sedimentology, 54, 243-264. doi: 10.1111/ j.1365-3091.2006.00833.x

DORA, O.Ö. (2007): Menderes Masifi'ndeki Jeolojik Araştırmaların Tarihsel Gelişimi [Historical development of geologic research of the Menderes Massive - in Turkish].- Menderes Masifi Kollukyumu (Menderes Massive Colluquim), 1-7.

DUNHAM, R.J. (1962): Classification of carbonate rocks according to a depositional texture--AAPG Memoir, 1, 108-121.

EBERLI, G.P. (1987): Carbonate turbidite sequences deposited in rift-basins of the Jurassic Tethys Ocean (eastern Alps, Switzerland).- Sedimentology, 34, 363-388. doi: 10.1111/j.1365-3091.1987.tb00576.x

EBERLI, G.P. (1991): Calcareous turbidites and their relationship to sea-level fluctuations and tectonism.- Cycles and events in stratigraphy, 340-359.

EMBRY, A.F. \& KLOVAN, E. (1971): A Late Devonian reef tract on northeastern Banks Island, Northwest Territories.- Can. Petrol. Geology Bull, 19, 730-781.

ERAKMAN, B., MESHUR, M., GÜL, M.A., ALKAN, H., ÖZTAŞ, Y. \& AKPINAR, M. (1982): Report of the geology and hydrocarbon potential of the Kalkan-KöycegizCameli-Tefenni area Depending on the Taurus Project.- Turkey Petroleum Corporation (TPC) Rep, Ankara (in Turkish, unpublished), 1732 p.

ERSOY, Ş. (1990): The Analysis of evolution and structural items of the Western Taurus - Lycia - Nappes (Batı Toroslar-Likya Naplarının yapısal birimleri ve evrimsel analizi).- Jeoloji Mühendisliği Dergisi (Geological Engineering) (in Turkish), 37, 5-16.

ERSOY, Ş. (1991): Stratigraphy and tectonics of the Datça (Muğla) peninsula (Datça yarımadasının stratigrafisi ve jeolojisi).- Türkiye Jeoloji Bülteni (Geological Bulletin of Turkey) (in Turkish), 34/2, 1-14.

ESCHARD, R. \& JOSEPH, P. (2002): Comparisons of reservoir architecture in a high transport efficiency basin floor fan (Pab Sandstone, Pakistan) and in a confined turbidite system (Annot Sandstone, France) from outcrop models.- AAPG Annual Meeting, Houston, Texas, USA.

EVERTS, A.J.W. (1991): Interpreting compositional variations of calciturbidites in relation to platform-stratigraphy: an example from the Paleogene of SE Spain.- Sedimentary Geology, 71, 231-242. doi: 10.1016/0037-0738(91)90104-L

FLÜGEL, E. (2004): Microfacies of Carbonate Rocks. Analysis, Interpretation and Application.- Berlin, Heidelberg, New York: Springer-Verlag, 976 p.

FOLK, R.L. (1962): Spectral subdivision of limestone types.- IN: HAM, W.E. (ed.): Classification of Carbonate Rocks. Am. Ass. Petrol. Geologists Mem., 1, 62-84.

FOLK, R.L. (1980): Petrology of Sedimentary Rocks (pdf).- Austin (Texas), Hemphill.

GARCIACARO, E., MANN, P. \& ESCALONA, A. (2011): Regional structure and tectonic history of the obliquely colliding Columbus foreland basin, offshore Trinidad and Venezuela.- Marine and Petroleum Geology, 28, 126-148. doi: 10.1016/j.marpetgeo.2009.08.016

GERVAIS, A., SAVOYE, B., PIPER, D.J.W., MULDER, T., CREMER, M. \& PICHEVIN, L. (2004): Present morphology and depositional architecture of a sandy confined submarine system: the Golo turbidite System, eastern margin of Corsica.- In: LOMAS, S.A. \& JOSEPH, P. (eds.): Confined Turbidite Systems. Geological Society, London, Special Publications, 222, 59-91. doi: 10.1144/GSL.SP.2004.222.01.05

GÖNCÜOĞLU, M.C. (2011): Geology of the Kütahya-Bolkardağ Belt.- Maden Tetkik ve Arama Dergisi (Bulletin of the Mineral Research and Exploration), 142, 223-277.

GRABAUA, W. (1904): On the classification of sedimentary rocks.-Am. Geologist, 33, 228-247.

GRACIANSKY, P.C. de, LEMOINE, M., LYS, M. \& SIGAL, J. (1967): Güney Anadolu Silsilesinin (Fethiye Kuzeyi) Batı Ucundaki Üst Paleozoik Ve Mesozoikte Stratigrafik Bir Kesit [A Stratigraphic Section in Upper Paleozoic and Mesozoic at the Western End of the Southern Anatolian Range (North of Fethiye) - in Turkish].Maden Tetkik ve Arama Dergisi (Bulletin of the Mineral Research and Exploration), $69,11-32$ 
GRACIANSKY, P.C. de. (1968): Stratigraphie des unités superposées dans le Taurus lycien et place dans l'arc dinaro-taurique.- Maden Tetkik ve Arama Dergisi (Bulletin of the Mineral Research and Exploration), 71, 42-62.

GÜL, M., GÜRBÜZ, K. \& CRONIN, B.T. (2011): Provenance of the Northern Part of the Kahramanmaraş Peripheral Foreland Basin (Miocene, S Turkey).- Journal of Asian Earth Science, 40/2, 475-495. doi: 10.1016/j.jseaes.2010.09.012

GÜL, M., CRONIN, B.T. \& GÜRBÜZ, K. (2012): Confined Deep Water System Development on the Accretionary Wedge (Miocene, Kahramanmaras Foreland Basin, S Turkey).-Earth-Science Reviews, 114/3-4, 195-217. doi: 10.1016/j.earscirev.2012. 06.002

GÜL, M., AKSOY, M.E., AKÇER, S., AVSAR, Ö. \& AVSAR, U. (2013): The lithological characteristics of the chert limestone and calciturbidites of the Babadağ Formation (Jurassic-Cretaceous Tavas Nappe, Ortaca, Mugla, SW Turkey).-66th Turkish Geological Congress, Ankara (in Turkish with English Abstract), 375 p.

GÜL, M. (2015): Occurrences of Chert in Jurassic-Cretaceous Calciturbidites (SW Turkey).- Open Geosciences, 7, 446-464. doi: 10.1515/geo-2015-0029

GÜL, M., GÜRBÜZ, K., \& CRONIN, B.T. (2015): Irregular plate boundary controls on Foreland Basin sedimentation (Miocene, Kahramanmaras).- Journal of Asian Earth Science, 111, 804-818. doi: 10.1016/j.jseaes.2015.07.018

GÜRBÜZ, K. (1999): Regional implications of structural and eustatic controls in the evolution of submarine fans: an example from the Miocene Adana Basin, Southern Turkey.-Geological Magazine, 136/3,311-319. doi: 10.1017/S0016756899002617

HAAS, J., GÖTZ, A.E. \& PÁLFY, J. (2010): Late Triassic to Early Jurassic palaeogeography and eustatic history in the NW Tethyan realm: New insights from sedimentary and organic facies of the Csővár Basin (Hungary).- Palaeogeography, Palaeoclimatology, Palaeoecology, 291, 456-468. doi: 10.1016/j.palaeo.2010.03.014

HAIRABIAN, A., BORGOMANO, J., MASSE, J.P. \& NARDON, S. (2015): 3-D stratigraphic architecture, sedimentary processes and controlling factors of Cretaceous deep-water resedimented carbonates (Gargano Peninsula, SE Italy).- Sedimentary Geology, 317, 116-136. doi: 10.1016/j.sedgeo.2014.11.001

HAUGHTON, P.D.W. (1994): Deposits of deflected and ponded turbidity currents, Sorbas Basin, southeastern Spain.- Journal of Sedimentary Research, 64, 223-246.

HAUGHTON, P.D.W. (2000): Evolving turbidite systems on a deforming basin floor, Tabernas, SESpain.-Sedimentology,47,497-518.doi:10.1046/j.1365-3091.2000.00293.x

KOÇ, H., TASLI, K. \& ÖZER, E. (2016): Bolkar Dağları ve Aladağlar'daki (Orta-Doğu Toroslar) Ofiyolitik Melanjla İlişkili Türbiditik İstiflerin Yaşı ve Paleo-Tektonik Yorumu [Age and Paleo-Tectonic Interpretation of Turbiditic Sequences Associated with Ophiolitic Melange in Bolkar Mountains and Aladağlar (Middle-Eastern Taurus) - in Turkish].- Türkiye Bilimsel ve Teknolojik Araştırma Kurumu (TUBITAK) (The Scientific and Technological Research Council of Turkey), Project No: 112 Y362

KONAK, N. (2003): Menderes Masifinin Güneydoğusundaki Naplı Yapılar [Nappe Structures in the Southeast of the Menderes Massif - in Turkish].- 56. Türkiye Jeoloji Kurultay1 (56. Geological Congress of Turkey), 304-306.

KORE, M.B. \& GÜL, M. (2017): Tavas Nap1 Üst Kretase Kalsitürbiditlerinin Sedimantolojik Özellikleri, Bileşimsel Değişimleri ve Çökelimini Kontrol Eden Faktörler [Sedimantological Properties, Compositional Changes and Controlling Factors of Sedimentation of Tavas Nappe Upper Cretaceous Calciturbidites - in Turkish].Muğla Sıtkı Koçman University VI. Science Research Symposium) Muğla-Turkey, $47 \mathrm{p}$.

KORE, M.B. (2018): Compositional Changes, Controlling Factors in Sedimentation and Sedimentological Characteristics of Upper Cretaceous Aged Calciturbidite of Tavas Nappe, (Lycian Nappes, Muğla, SW Turkey).- Mugla Sttk1 Koçman University, Institute of Natural and Applied Sciences, MSc Thesis, $121 \mathrm{p}$.

KOZUR, H.W. (1998): The age of the siliciclastic series (Karareis Formation) of the western Karaburun Peninsula, western Turkey.- Paleontologia Polonica, 58, 171-189.

KOZUR, H.W., ŞENEL, M. \& TEKIN, K. (1998): First evidence of Hercynian Lower Carboniferous flyschoid deep-water sediments in the Lycian Nappes, southwestern Turkey.- Geologia Croatica, 51/1, 15-22.

LE GOFF, J., CEREPI, A., SWENNEN, R., LOISY, C., CARON, M., MUSKA, K. \& EL DESOUKY, H. (2015): Contribution to the understanding of the Ionian Basin sedimentary evolution along the eastern edge of Apulia during the Late Cretaceous in Albania.- Sedimentary Geology, 317, 87-101. doi: 10.1016/j.sedgeo.2014.09.003

LOMAS, S.A. \& JOSEPH, P. (2004): Confined Turbidite Systems.-- Geological Society London Special Publication, 222, 1-7. doi: 10.1144/GSL.SP.2004.222.01.01

MCBRIDE, E.F., ABDEL-WAHAB, A. \& EL-YOUNSY, A.R.M., (1999): Origin of spheroidal chert nodules, Drunka Formation (Lower Eocene), Egypt.- Sedimentology, 46, 733-755. doi: 10.1046/j.1365-3091.1999.00253.x

MICHALÍK, J., LINTNEROVÁ, O., REHÁKOVÁ, D., BOOROVÁ, D. \& SIMO, V. (2012): Early Cretaceous sedimentary evolution of a pelagic basin margin (the Manín Unit, central Western Carpathians, Slovakia).- Cretaceous Research, 38, 68-79. doi: 10.1016/j.cretres.2012.02.006

MOIX, P., VACHARD, D., ALLIBON, J., MARTINI, R., WERNLI, R., KOZUR, H.W. \& STAMPFLI, G.M. (2013): Palaeotethyan, Neotethyan and Huğlu-Pindos Series in the Lycian Nappes (SW Turkey): Geodynamical Implications.- In: TANNER,
L.H., SPIELMANN, J.A. \& LUCAS, S.G. (eds.): The Triassic System. New Mexico Museum of Natural History and Science Bulletin, 61, 401-444.

NEUMANN, P. \& ZACHER, W. (2004): The Cretaceous sedimentary history of the Pindos Basin (Greece).- Int. J. of Earth Sciences (Geol Rundsch), 93, 119-131. doi: 10.1007/s00531-003-0358-3

OKAY, A. (1989): Denizli güneyinde Menderes Masifi ve Likya Naplarının jeolojisi [Geology of Menderes Massif and Lycian Nappes in south of Denizli - in Turkish].Maden Tetkik ve Arama Dergisi (Bulletin of the Mineral Research and Exploration), $109,45-58$.

OKAY,A. (2001): Stratigraphic and metamorphic inversions in the central Menderes Massif: a new structural model.- Int. J. of Earth Sciences, 89, 709-727. doi: 10.1007/ s005310000098

ÖZCAN, Z., OKAY, A.I., ÖZCAN, E., HAKYEMEZ, A. \& ÖZKAN-ALTINER, S. (2012): Late Cretaceous-Eocene Geological Evolution of the Pontides Based on New Stratigraphic and Palaeontologic Data Between the Black Sea Coast and Bursa (NW Turkey).- Turkish Journal of Earth Sciences, (Turkish J. Earth Sci.), 21, 933-960.

PAYROS, A. \& PUJALTE, V. (2008): Calciclastic submarine fans: An integrated overview.- Earth-Science Reviews, 86/1-4, 203-246. doi: 10.1016/j.earscirev. 2007.09.001

POISSON, A. (1977): Recherches géologiques dans les Taurides occidentals (Turquie).Ph.D. thesis, Paris-Sud (centre d'Orsay), Paris, 795 p.

PRICE, I. (1977): Deposition and derivation of clastic carbonates on a Mesozoic continental margin, Othris, Greece.-Sedimentology, 24, 529-546. doi: 10.1111/j. 13653091.1977.tb00137.x

READING, H.G. (1991): The classification of deep-sea depositional systems by sediment calibre and feeders system.- Journal of Geological Society of London, 148, 427-430.

REIJMER, J.J.G., TEN KATE, W.G.H.Z., SPRENGER, A. \& SCHLAGER, W. (1991): Calciturbidite composition related to exposure and flooding of a carbonate platform (Triassic Eastern Alps).- Sedimentology, 38, 1059-1074. doi: 10.1111/j. 13653091.1991.tb00371.x

REIJMER, J.J.G., PALMIERI, P., FLOQUET, M., KERKVLIET, S. \& GROEN, R. (2008): Carbonate turbidites and debris flows: Sea-level variations versus tectonic processes.- International Geological Congress, Oslo, HPS-12 New developments in stratigraphic classification.

REIJMER, J.J.G., PALMIERI, P. \& GROEN, R. (2012): Compositional variations in calciturbidites and calcidebrites in response to sea-level fluctuations (Exuma Sound, Bahamas).- Facies, 58, 493-507. doi: 10.1007/s10347-011-0291-Z

REIJMER, J.J.G., MULDER, T. \& BORGOMANO, J. (2015a): Carbonate slopes and gravity deposits.- Sedimentary Geology, 317, 1-8. doi: 10.1016/j.sedgeo. 2014.12.001

REIJMER, J.J.G., PALMIERI, P., GROEN, R. \& FLOQUET, M. (2015b): Calciturbidites and calcidebrites: Sea-level variations or tectonic processes.- Sedimentary Geology, 317, 53-70. doi: 10.1016/j.sedgeo.2014.10.013

RICHARDS, M., BOWMAN, M. \& READING, H.G. (1998): Submarine-fan system I: characterization and stratigraphic prediction.- Marine and Petroleum Geology, 15, 689-717. doi: 10.1016/S0264-8172(98)00036-1

ROBERTSON, A.H.F. \& WOODCOCK, N.H. (1981): Alakir çay Group, Antalya complex, SW Turkey: A deformed Mesozoic carbonate margin.-- Sedimentary Geology, 1/2, 95-131. doi: 10.1016/0037-0738(81)90015-4

ROBERTSON, A.H.F. \& DIXON, J.E. (1996): Introduction to aspects of the geological evolution of the Eastern Mediterranean.- In: DIXON, J.E. \& ROBERTSON, A.H.F. (eds.): The Geological Evolution of the Eastern Mediterranean. Geological Society Special Publication, 17, 1-75. doi: 10.1144/GSL.SP.1984.017.01.02

ROBERTSON, A.H.F. (2000): Mesozoic-Cenozoic tectonic-sedimentary evolution of a south Tethyan oceanic basin and its margins in southern Turkey.- In: BOZKURT, E., WINCHESTER, J.A. \& WIPER, J.D.A. (eds.): Tectonics and Magmatism in Turkey and the Surrounding Area. Geological Society, London, Special Publication, $173,97-138$.

ROBERTSON, A.H.F. (2002): Overview of the genesis and emplacement of Mesozoic ophiolites in the Eastern Mediterranean Tethyan region.- Lithos, 65, 1-67. doi: 10.1016/S0024-4937(02)00160-3

ROBERTSON, A.H.F. \& MOUNTRAKIS, D. (2006): Tectonic development of the Eastern Mediterranean region: an introduction.- In: ROBERTSON, A.H.F. \& MOUNTRAKIS, D. (eds.): Tectonic Development of the Eastern Mediterranean Region. Geological Society, London, Special Publications, 260, 1-11. doi: 10.1144/GSL. SP.2006.260.01.01

RUBERT, Y., JATI, M., LOISY, C., CEREPI, A., FOTO, G. \& MUSKA, K. (2012): Sedimentology of resedimented carbonates facies and geometrical characterisation of an upper Cretaceous calciturbidite system in Albania.- Sedimentary Geology, 257, 63-77. doi: 10.1016/j.sedgeo.2012.02.009

SALLER, A., BALL, B., ROBERTSON, S., MCPHERSON, B., WENE, C., NIMS, R. \& GOGAS, J. (2001): Reservoir characteristics of Devonian cherts and their control on oil recovery: Dollarhide Field, West Texas.-AAPG Bull., 85, 35-50. 
SARI, B. \& ÖZER, S. (2001): Facies characteristics of the Cenomanian-Maastrichtian Sequence of the Beydağları carbonate platform, Korkuteli area, Western Taurides, Turkey.- International Geology Review, 43, 830-839. doi: 10.1080/ 00206810109465050

SARI, B. \& ÖZER, S. (2002): Upper Cretaceous stratigraphy of the Beydağları carbonate platform, Korkuteli area (Western Taurides, Turkey).- Turkish Journal of Earth Sciences, 11/1, 39-59.

SARI, B., STEUBER, T. \& ÖZER, S. (2004): First record of Upper Turonian rudists (Mollusca, Hippuritoidea) in the Bey Dağları carbonate platform, Western Taurides (Turkey): taxonomy and strontium isotope stratigraphy of Vaccinites praegiganteus (Toucas, 1904).- Cretaceous Research, 25/2, 235-248.

SARI, B. (2006): Upper Cretaceous planktonic foraminiferal biostratigraphy of the Bey Dağları autochthon in the Korkuteli area, Western Taurides, Turkey.- Journal of Foraminiferal Research, 36, 241-261. doi: 10.2113/gsjfr.36.3.241

SARI, B., KANDEMIR, R., ÖZER, S., WALASZCZYK, I., GÖRMÜŞ, M., DEMIRCAN, H. \& YILMAZ, C. (2014): Upper Campanian calciclastic turbidite sequences from the Hacımehmet area (eastern Pontides, NE Turkey) integrated biostratigraphy and microfacies analysis.- Acta Geologica Polonica, 64/4, 393-418. doi: 10.2478/agp2014-0022

SARI, B. (2017): Lithostratigraphy and planktonic foraminifera of the uppermost Cretaceous-Upper Palaeocene strata of the Tavas nappe of the Lycian nappes (SW Turkey).- Geologia Croatica, 70/3, 163-177. doi: 10.4154/gc.2017.14

SAVARY, B., OLIVERO, D. \& GAILLARD, C. (2004): Calciturbidite dynamics and endobenthic colonisation: example from a late Barremian (Early Cretaceous) succession in southeastern France.- Palaeogeography, Palaeoclimatology, Palaeoecology, 211, 221-239. doi: 10.1016/j.palaeo.2004.05.008

SKOURTSIS-CORONEOU, V., SOLAKIUS, N. \& CONSTANTINIDIS, I. (1995): Cretaceous stratigraphy of the Ionian Zone, Hellenides, western Greece.- Cretaceous Research, 16, 539-558. doi: 10.1006/cres.1995.1035

SOFRACIOĞLU, D. \& KANDEMIR, R. (2013): The Upper Cretaceous calciclastic submarine fan deposits in the Eastern Pontides, NE Turkey: facies architecture and controlling factors.- Turkish J. Earth Sci., 22, 588-610

SOLAK, C., TASLI, K. \& SARI, B. (2015): Stratigraphy and depositional history of the Cretaceous carbonate successions in the Spil Mountain (Manisa, W Turkey).- Cretaceous Research, 53, 1-18. doi: 10.1016/j.cretres.2014.10.008

SOYCAN, H., TEKIN, U.K., ERDOĞAN, K. \& KONAK, N. (2009): Aalenian-lower Bathonian (Middle Jurassic) radiolarian faunas from the Tavas nappe, Denizli, western Turkey: Dating of the major drowning event in the Tauride platform.- The 12th Meeting of the International Association of Radiolarian Paleontologists, China, 257-259.

SOYCAN, H., TEKIN, U.K., YILMAZ, İ.Ö., ERDOĞAN, K., KONAK, N. \& OCAKOĞLU, F. (2011): Paleoceanographic Significance of a Platform Drowning Event in The Liassic-Early Dogger of the Tavas Nappe, Western Taurides, SW Turkey, Paleontological and Sedimentological Approaches.- 64. Türkiye Jeoloji Kurultay1, (64th Geological Congress of Turkey) (in Turkish), 262-263.

SOYCAN, H., ERDOĞAN, K. \& KONAK, N. (2015): Aalenian-Early Bathonian (Middle Jurassic) radiolarian assemblages in the Tavas nappe within Lycian nappes in the western Taurides (SW Turkey): The first dating of carbonate platform drowning.- Journal of Asian Earth Sciences, 104, 3-21. doi: 10.1016/j.jseaes.2014.08.002

SENEL, M., SELCCUK, H., BILGIN, Z.R., SEN, M.A., KARAMAN, T., ERKAN, M., DINÇER, M.A., DURUKAN, E., ARBAS, A., KAYMAKÇI, H., ÖRÇEN, S. \& BiLGiN, C. (1989): Çameli (Denizli) - Yeşilova (Burdur) - Elmalı (Antalya) ve dolayının jeolojisi [Geology of Çameli (Denizli) - Yeşilova (Burdur)-Elmalı (Antalya) and vicinity - in Turkish, unpublished].- General Directorate of Mineral Research and Exploration (MTA), Rep. no: 9429.
ŞENEL, M., AKDENIZ, N., ÖZTÜRK, E.M., ÖZDEMIR, T., KADINKIZ, G., METIN, Y., ÖCAL, H., SERDAROĞLU, M. \& ÖRÇEN, S. (1994): Fethiye (Muğla)-Kalkan (Antalya) ve kuzeyinin jeolojisi [Geology of Fethiye (Muğla)-Kalkan (Antalya) and the north - in Turkish, unpublished].- General Directorate of Mineral Research and Exploration (MTA), Ankara, Rep. no: 976:121 p.

ŞENEL, M. (1997a): 1 / 100000 ölçekli Türkiye Jeoloji Haritaları, No:1, Fethiye - L7 Paftas1 [1 / 100000 scaled geological map of Turkey, No. 1, Fethiye - L7 Sheet - in Turkish, unpublished].- General Directorate of Mineral Research and Exploration (MTA), $17 \mathrm{p}$

ŞENEL, M. (1997b): 1 / 100000 ölçekli Türkiye Jeoloji Haritaları, No:1, Fethiye - L8 Paftas1 [1 / 100000 scaled geological map of Turkey, No. 1, Fethiye - L8 Sheet - in Turkish, unpublished].- General Directorate of Mineral Research and Exploration (MTA), 22p

ŞENEL, M. (1997c): 1 / 100000 ölçekli Türkiye Jeoloji Haritaları, No:1, Fethiye - L9 Paftas1 [1 / 100000 scaled geological map of Turkey, No. 1, Fethiye - L9 Sheet - in Turkish, unpublished].- General Directorate of Mineral Research and Exploration (MTA), $20 \mathrm{p}$.

ŞENEL, M., DALKILIÇ, H., GEDIK, İ., SERDAROĞLU, M., METIN, S., ESENTÜRK, K., BÖLÜKBAȘI, A.S. \& ÖZGÜL, N. (1998): Orta Toroslar'da Güzelsu Koridoru ve Kuzeyinin Jeolojisi [Geology of Güzelsu Corridor and North in the Middle Taurus - in Turkish].- Maden Tetkik ve Arama Dergisi (Bulletin of the Mineral Research and Exploration), 120, 171-197.

ŞENEL, M. (2004): Stratigraphic and structural features of the Yeşilbarak Nappe in Western Taurus range and its comparison with the similar units in SE Anatolia and North Cyprus.- Maden Tetkik ve Arama Dergisi (Bulletin of the Mineral Research and Exploration ) (in Turkish), 128, 1-26.

ŞENEL, M. (2007): Likya Naplarının Özellikleri ve Evrimi (Characteristic Features of the Lycian Nappes and Their Evolution).- Menderes Masifi Kolukyumu (Colluqium on Menderes Massif), 51-55.

SENGÖR, A.M.C. \& YILMAZ, Y. (1981): Tethyan evolution of Turkey: a plate tectonic approach.- Tectonophysics, 75, 181-241. doi: 10.1016/0040-1951(81)90275-4

SENGÖR, A.M.C., SATIR, M. \& AKKÖK, R. (1984): Timing of tectonic events in the Menderes Massif, western Turkey: Implications for tectonic evolution and evidence for Pan-African basement in Turkey.- Tectonics, 3/7, 693-707. doi: 10.1029/ TC003i007p00693

TEKELİ, O. (1984): Geology of the Taurus Belt.- In: TEKELİ, O. \& GÖNCÜOĞLU, C. (eds.): Proceedings of the International Symposium Geology of the Taurus Belt. Maden Tetkik ve Arama Enstitüsü (General Directorate of Mineral and Research and Exploration), Ankara-Turkey, $342 \mathrm{p}$.

UDDEN, J.A. (1914): Mechanical composition of clastic sediments.--Geological Society of America Bulletin, 25/1, 655-744. doi: 10.1130/GSAB-25-655

VACEK, F. (2007): Carbonate microfacies and depositional environments of the Silurian - Devonian boundary strata in the Barrandian area (Czech Republic).- Geologica Carpathica, 58/6, 497-510.

VACHARD, D. \& MOIX, P. (2011): Late Pennsylvanian to Middle Permian revised algal and foraminiferan biostratigraphy and palaeobiogeography of the Lycian Nappes (SW Turkey): Palaeogeographic implications.- Revue de micropaléontologie, 54, 141-174. doi: 10.1016/j.revmic.2011.02.002

WATTS, K.F. (1987): Triassic carbonate submarine fans along the Arabian platform margin, Sumeini Group, Oman.- Sedimentology, 34, 43-71. doi: 10.1111/j. 13653091.1988.tb00904.x

WENTWORTH, C.K. (1922): A Scale of Grade and Class Terms for Clastic Sediments.The Journal of Geology, 30/5, 377-392. doi: 10.1086/622910

YILMAZ, Y. (1981): Sakarya kıtası güney kenarının tektonik evrimi [The tectonic evolution of the southern edge of the Sakarya continent - in Turkish].- İstanbul Yerbilimleri (Istanbul Journal of Earth Sciences), 1/1-2, 33-52. 